\title{
The rheological behaviour of fracture-filling cherts: example of Barite Valley dikes, Barberton Greenstone Belt, South Africa
}

\author{
M. Ledevin ${ }^{1}$, N. Arndt ${ }^{1}$, A. Davaille ${ }^{2}$, R. Ledevin ${ }^{3}$, and A. Simionovici ${ }^{1}$ \\ ${ }^{1}$ ISTerre, CNRS, 38041 Grenoble CEDEX 9, France \\ ${ }^{2}$ FAST, CNRS, Univ. Paris Sud, Orsay CEDEX, France \\ ${ }^{3}$ LBBE, CNRS, Univ. Lyon 1, 69622 Villeurbanne CEDEX, France \\ Correspondence to: M. Ledevin (morgane.ledevin@gmail.com)
}

Received: 7 April 2014 - Published in Solid Earth Discuss.: 13 May 2014

Revised: 19 December 2014 - Accepted: 30 January 2015 - Published: 20 February 2015

\begin{abstract}
In the Barberton Greenstone Belt, South Africa, a 100-250 m thick complex of carbonaceous chert dikes marks the transition from the Mendon Formation to the Mapepe Formation (3260 Ma). The sub-vertical- to vertical position of the fractures, the abundance of highly shattered zones with poorly rotated angular fragments and common jigsaw fit, radial structures, and multiple injection features point to repetitive hydraulic fracturing that released overpressured fluids trapped within the shallow crust. The chemical and isotopic compositions of the chert favour a model whereby seawaterderived fluids circulated at low temperature $\left(<100-150{ }^{\circ} \mathrm{C}\right)$ within the shallow crust.

From the microscopic structure of the chert, the injected material was a slurry of abundant clay-sized, rounded particles of silica, carbonaceous matter and minor clay minerals, all suspended in a siliceous colloidal solution. The dike geometry and characteristics of the slurry concur on that the chert was viscoelastic, and most probably thixotropic at the time of injection: the penetration of black chert into extremely fine fractures is evidence for low viscosity at the time of injection and the suspension of large country rock fragments in the chert matrix provides evidence of high viscosity soon thereafter. We explain the rheology by the particulate and colloidal structure of the slurry, and by the characteristic of silica suspensions to form cohesive 3-D networks through gelation.

Our results provide valuable information about the compositions, physical characteristics and rheological properties of the fluids that circulated through Archean volcanosedimentary sequences, which is an additional step to under-
\end{abstract}

stand conditions on the floor of Archean oceans, the habitat of early life.

\section{Introduction}

Siliceous sediments are common in many Palaeoarchean greenstone belts. A recurrent pattern consists of conformable, bedded chert sequences overlying pervasively silicified volcanic units (e.g. de Wit et al., 1982; Paris et al., 1985; Lowe and Byerly, 1986a; Hofmann and Harris, 2008). In several places, dikes filled by siliceous- and carbonaceousrich material cut through the volcanic and sedimentary units (e.g. Lowe and Knauth, 1977; Lowe and Byerly, 2003; Ueno et al., 2004; Hofmann, 2005; de Vries et al., 2006; Van Kranendonk, 2006; Hofmann and Bolhar, 2007; de Wit et al., 2011). Such successions are recognized worldwide, the bestpreserved and least metamorphosed examples being in the Pilbara belt in Western Australia (e.g. Nijman et al., 1998; Kiyokawa et al., 2006, 2012; Van Kranendonk, 2006) and the Barberton belt in South Africa (e.g. Lowe and Knauth, 1977; Lowe and Byerly, 2003; de Vries et al., 2006; de Wit et al., 2011).

Some authors (e.g. Nijman et al., 1998; Brasier et al., 2002, 2005; Hofmann, 2005; Kiyokawa et al., 2006; Van Kranendonk, 2006) consider chert dikes as fossilized conduits of low-temperature hydrothermal circulation within sub-seafloor volcanic rocks; others (Lowe and Byerly, 2003; Lowe, 2013; Sleep and Lowe, 2014) envisage a meteorite impact that created open fractures on the seafloor subsequently filled by surface sediments. 

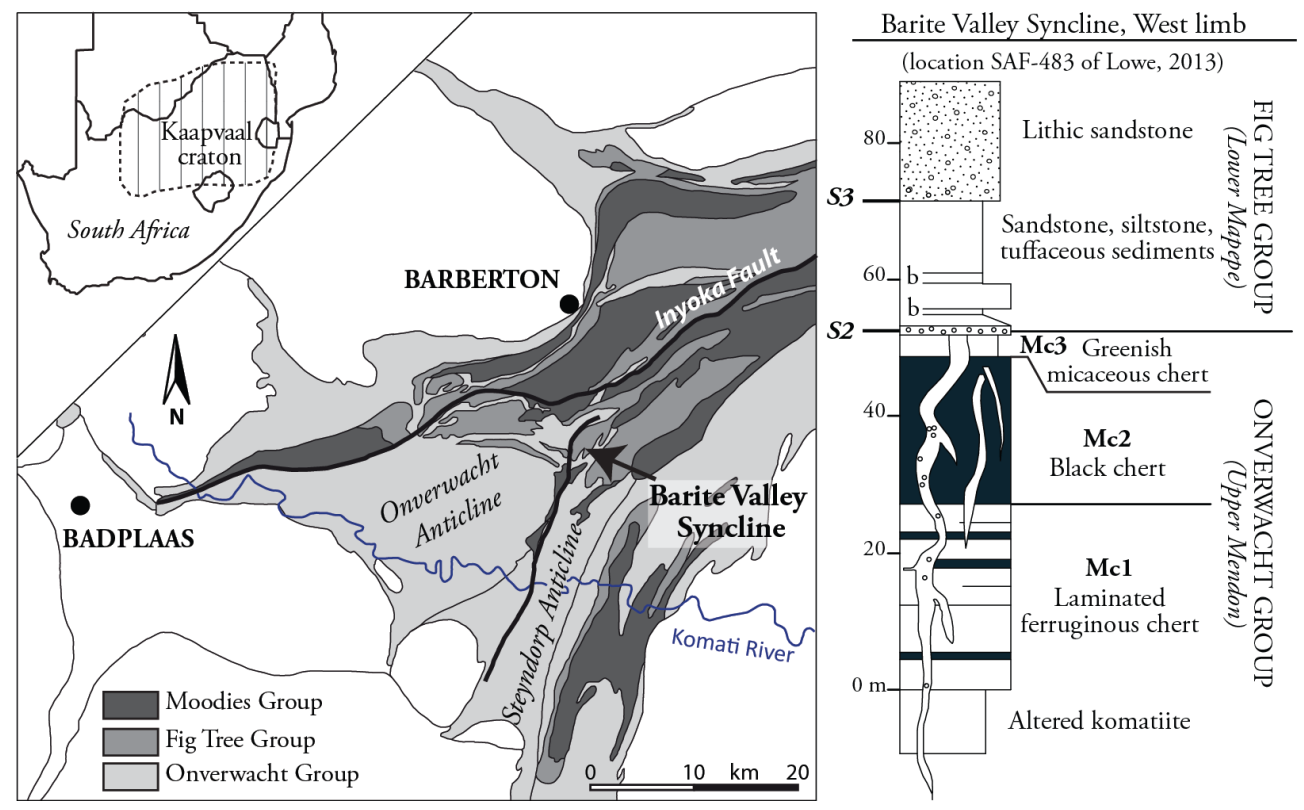

Figure 1. (Left) Simplified geological map of the Barberton Greenstone Belt and location of the Barite Valley Syncline. (Right) Stratigraphy of the western limb of the Barite Valley syncline, modified from Lowe (2013). The Onverwacht to Fig Tree transition is marked by the spherule bed S2 (Lowe and Byerly, 1986b) below which the dike complex of this study is found. The dikes begin in the sedimentary units M3c and M2c, cut through M1c and extent down to the Si-metasomatized komatiitic flows. "b" indicates the position of barite layers.

In this study, we use field observations at the Barite Valley site in the Barberton Greenstone belt to explore the origin and nature of the filling material. We combine the geometry and internal structures of the dikes, the macro- and microscopic characteristics of the chert, as well as chemical and isotopic data, to build a comprehensive model of the rheology of the fluid at the time it was injected. We depart from previous approaches by providing a dynamic view of the infilling process of Archean chert dikes, which offers a rare window to sub-seafloor hydrothermalism at that time.

\section{Barite Valley dikes: from field to microscopic characteristics}

\subsection{Studied area and dike location}

The geology of the Barberton belt is well described by Lowe and Nocita (1999), Furnes et al. (2011) and de Wit et al. (2011). The area we studied is on the western limb of the Barite Valley syncline (Fig. 1), where the uppermost units of the Mendon Formation (Onverwacht Group; 33353260 Ma; Kröner et al., 1991; Byerly et al., 1993, 1996) are conformably overlain by the lowermost units of the Mapepe Formation (Fig Tree Group; 3260-3225 Ma; Armstrong et al., 1990; Byerly et al., 1996) (Figs. 1, 2, 3a). The Mendon Formation comprises a series of silicified komatiite flows (Figs. 1, 2) (Duchac and Hanor, 1987; Hanor and Duchac, 1990; Hofmann and Harris, 2008; Lowe, 2013) followed by a $100 \mathrm{~m}$ thick unit of thinly laminated ferruginous cherts
(Mc1), massive and thickly bedded black cherts (Mc2) and greenish micaceous cherts (Mc3) (Fig. 3a), all deposited in a quiet, probably deep, subaqueous environment (Lowe, 2013).

These sedimentary units are folded and dip steeply to the S-SE (Fig. 3a) in agreement with the N-NE plunge of the Barite Valley syncline. Faults are common in the entire area but are not systematically linked to the presence of the dikes (Fig. 2). The chert dike system is restricted to the uppermost 100 to $250 \mathrm{~m}$ of the Mendon Formation (Lowe, 2013; Hofmann and Bolhar, 2007): dikes first appear in the lower komatiitic units (Figs. 2, 3a) (Hofmann and Bolhar, 2007; Lowe, 2013), cut across the ferruginous then carbonaceous banded chert units, and terminate in the greenish micaceous chert below a spherule bed (Fig. 1) (Lowe and Byerly, 1986b; Hofmann and Bolhar, 2007; Lowe, 2013). Most of the dikes are oriented W-NW and appear in clusters distributed through several hundreds of metres of outcrop (Fig. 2; Lowe, 2013). Typical examples are illustrated in Fig. 3b, c.

\subsection{Field descriptions}

The dikes are in sharp contact with the surrounding banded sediments and usually become narrower with depth (Lowe, 2013). They cut across the sedimentary rocks at a high angle, normally at 60 to $90^{\circ}$ to the bedding, indicating that the fractures were near-vertical when they formed (Lowe, 2013, reported values as low as $20-40^{\circ}$ ). Some smaller veins are parallel to the bedding and commonly root in larger and discordant dikes. 


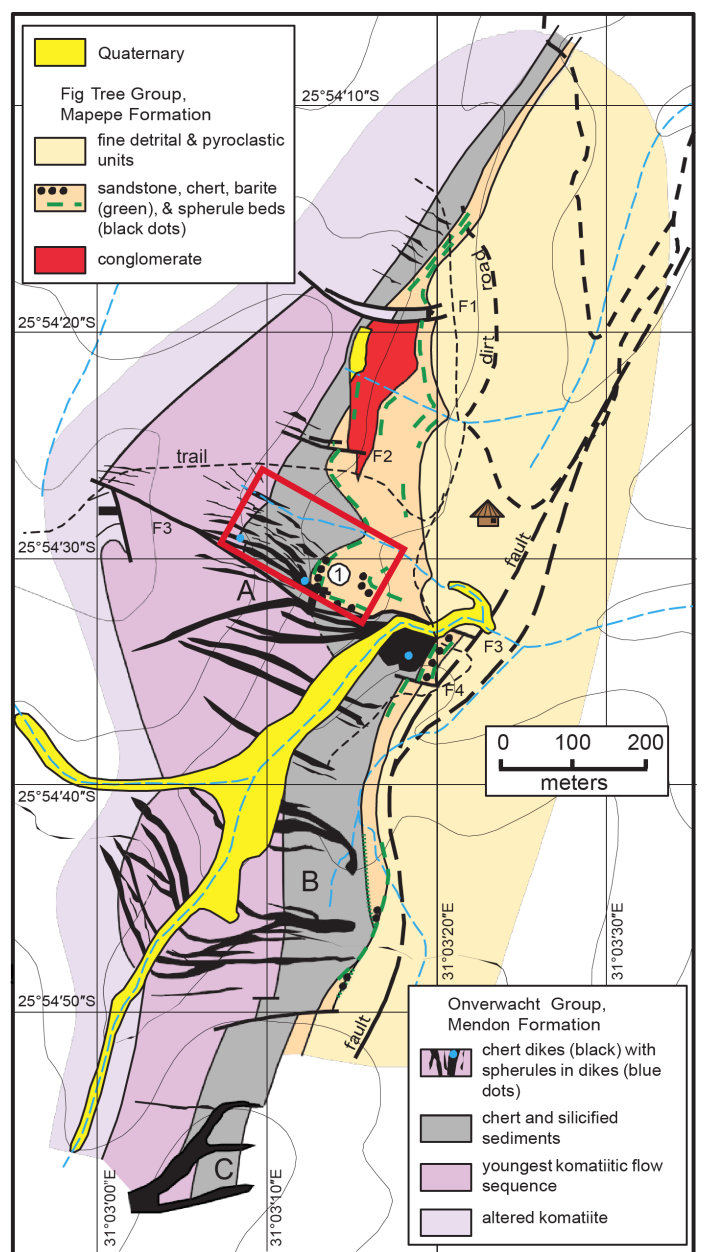

Figure 2. Geological map of the Barite Valley site from Lowe (2013) showing the repartition of the dikes (black). They start at the top of the Mendon Formation (grey) and extent downward through to the komatiitic units (pink). The red rectangle represents the studied area. Major faults are named F1 to F4.

We distinguish two major types of structures in the area: dikes filled with black chert and fragments of white silicified country rock (Figs. 3b, c, 4), and later, fragment-poor dikes filled with botryoidal or colloform silica (Fig. 5).

Fragment-rich dikes display a wide range of shapes, widths and fracture intensities, as illustrated in Figs. 3 to 8. They vary in width from a few centimetres to several metres ( $0.5-1 \mathrm{~m}$ on average, to a maximum of 5-8 $\mathrm{m})$. Some are filled entirely with semi-translucent black chert (Fig. 4a) but most are charged with centimetre (Fig. 4b-d) to decimetre (Fig. 3b) sized fragments of cream-to-white chert that clearly came from the surrounding banded units. The resulting structure is either matrix- (Fig. 4b) or clast-supported (Fig. 6) at outcrop scale, depending on the clast-to-matrix ratio and degree of fracturing.

The fragment-rich dikes have complex structures comprising numerous millimetre- to centimetre-thick veins that in-
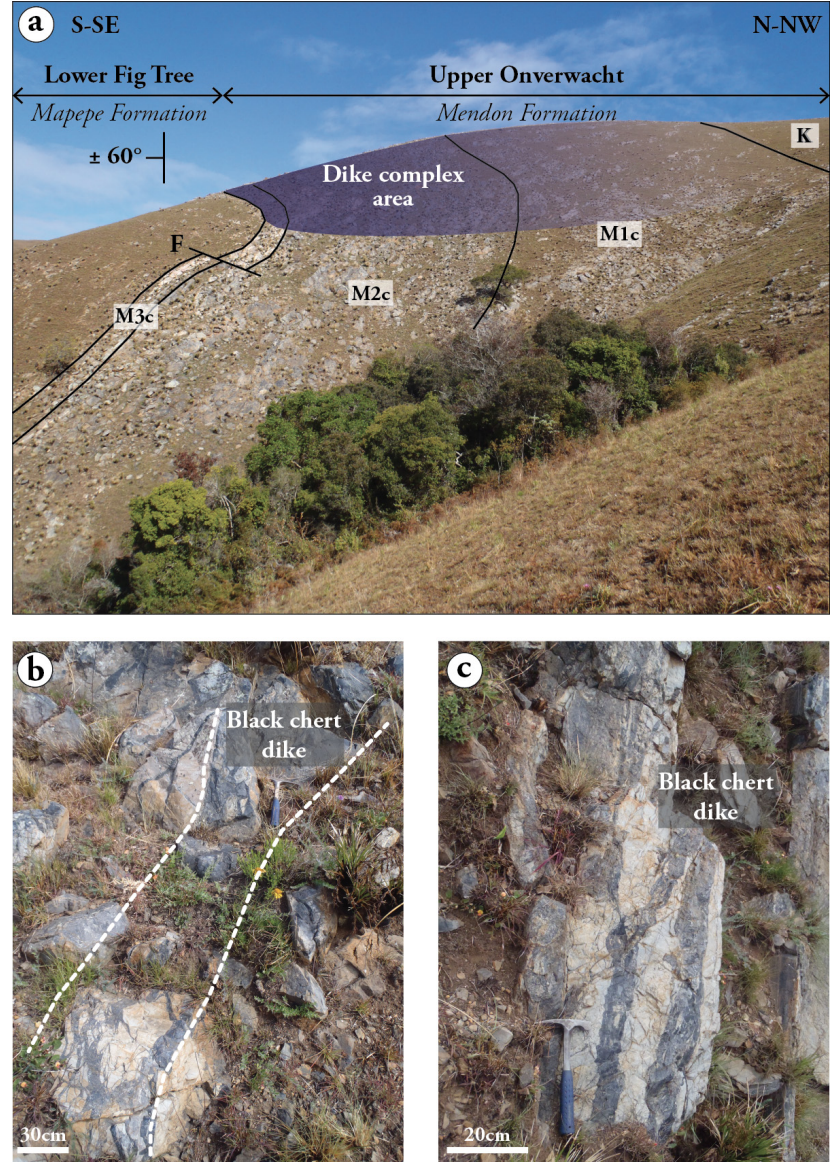

Figure 3. (a) Photo of the Barite Valley area (NE side of the hill) showing the main limits of the Mendon Formation and Mapepe Formation. The series gets younger to the S-SE and dips steeply at $\pm 60^{\circ}$ in the same direction. The main dike complex area begins in the sedimentary units M3c and extends down to the silicified komatiitic flows (K). Stratigraphy is detailed in Fig. 1b. Photos (b) and (c) are examples of black chert dikes cross-cutting the silicified rocks of the upper Mendon formation.

vade shattered fragments or branch out from the interior of the dike. The sequence in photos (a) to (c) of Fig. 4 illustrates the diverse shapes encountered in the area, from straight dikes to highly irregular fractures, the intermediate shape (b) being most common. In some dikes, multiple injection is inferred from the presence of internal zoning subparallel to fracture walls (Fig. 4d). The outmost layer is composed of silt-sized siliceous material (Fig. 4d), black or translucent chert, chalcedony or crystalline quartz.

Highly fractured zones commonly display "jigsawpuzzle" textures in which a continuous matrix of from $<1 \mathrm{~mm}$ wide to $1 \mathrm{~cm}$ wide veins of black chert envelopes little-displaced, minimally rotated, sub-angular to angular clasts of fine-grained country rock (Figs. 6, 7a). Evidence for intense fracturing is shown in Fig. $7 b$, where multiple thin 

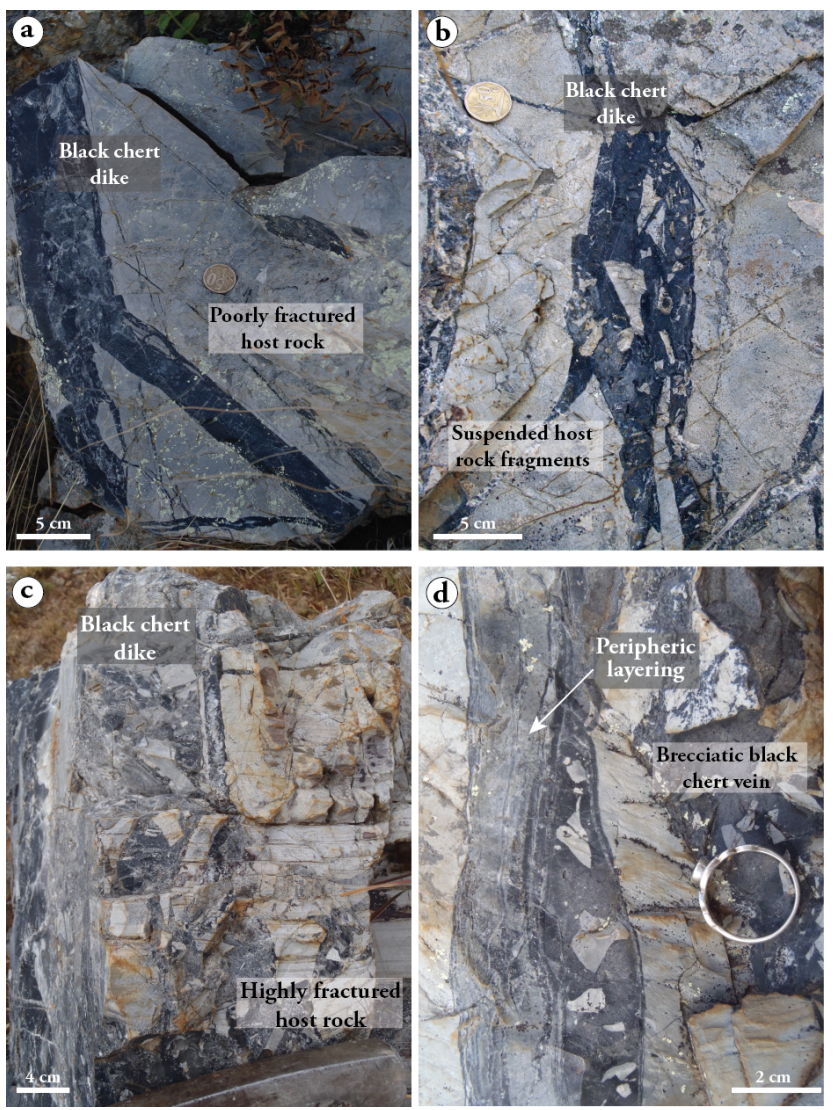

Figure 4. Main types of dikes encountered in the Barite Valley syncline with degree of fracturing increasing from photo (a) to photo (c). The fractures have straight and sharp (a) to irregular boundaries (c). They contain variable amount of country rock fragments embedded in a black chert matrix, leading to clast-supported (c) or matrix-supported (b) textures in outcrop. Internal layering (d) is common and indicates multiple fluid injections.

veins have a $360^{\circ}$ radial distribution around a highly fractured central zone.

Fragment-poor dikes are filled with black chert, commonly with botryoidal columnar structures $(>5 \mathrm{~cm}$ long) oriented perpendicular to the fracture walls (Fig. 5a), or colloform structures manifested by thin alternating black-and-white laminations $(<0.5 \mathrm{~mm}$; Fig. $5 \mathrm{c})$. In the vein illustrated in Fig. 8b, colloform textures occupy the centre of the fracture and a $2-3 \mathrm{~cm}$ thick zone of white, translucent silica lines the contact. Fragment-poor dikes cut across the fragment-rich dikes and are interpreted as later structures (Fig. 5a).

The host rock is a pale grey silicified shale consisting of phyllosilicates in a matrix of microquartz. Iron minerals (i.e. siderite) are abundant (up to $5 \%$ ) in some layers; carbonaceous matter is almost absent.
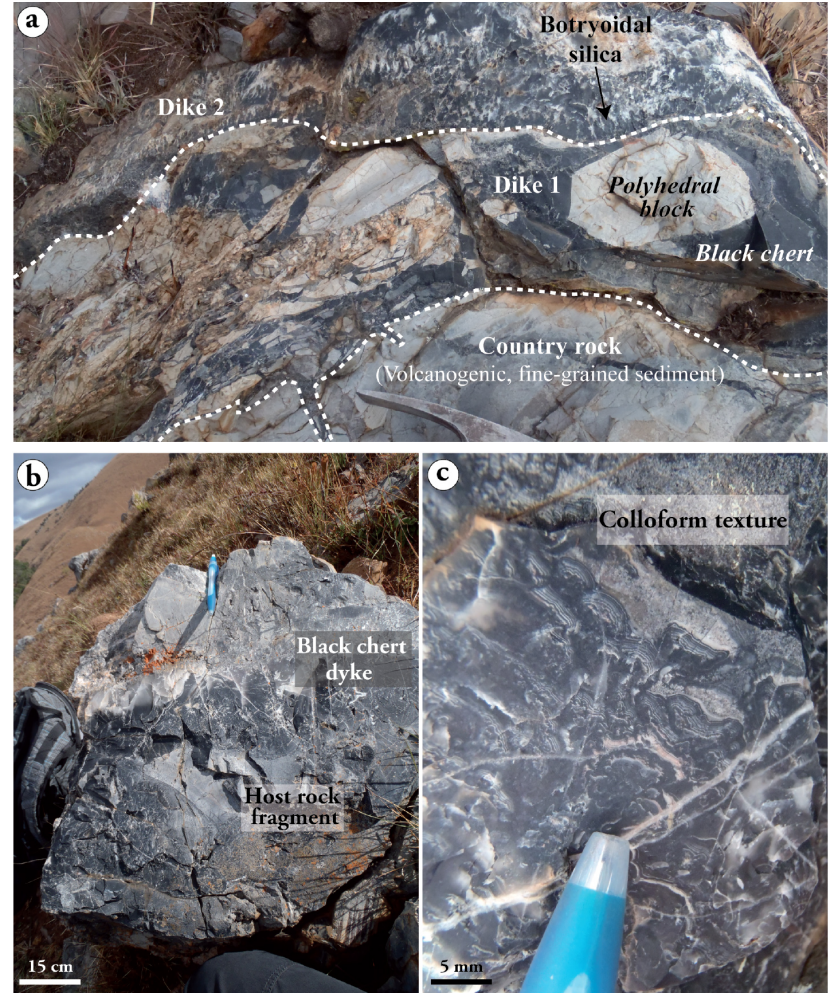

Figure 5. Examples of homogeneous dikes where host rock fragments are rare or absent. The silica precipitated to form either botryoidal columnar structures perpendicular to the fracture wall (a), or colloform structures alternating thin black-and-white laminations $(\mathbf{b}, \mathbf{c})$.

\subsection{Size and form of fragments in dikes}

As shown in Fig. 8, the fragments have polyhedral, spindlelike shapes covering a wide range of forms, from angular to sub-rounded. They vary in size from $<1 \mathrm{~cm}$ to $60-80 \mathrm{~cm}$ $(<10 \mathrm{~cm}$ on average; Figs. $3 \mathrm{~b}, 4 \mathrm{~b}-\mathrm{d})$ and are uniformly distributed within the dike. Their long axes are commonly subparallel to the fracture walls (Fig. 8b, d), especially when close to the contact.

Most of the fragments ( $>90 \%)$ were derived from adjacent bedded sediments, being similar in colour, grain size, structure and texture. They show little rotation or displacement, and occupy between $1 \%$ and $>50 \%$ of the volume of the dikes (Fig. 6). When abundant, they are clast-supported but when sparsely and uniformly distributed, the fragments are isolated within and probably supported by the black chert matrix.

Jigsaw textures (Fig. 6) consist of little-displaced, minimally rotated, sub-angular to angular clasts of fine-grained country rock within a network of fine veins of black chert. The fragments range in size from a few millimetres up to $10 \mathrm{~cm}$; the veins vary in thickness from $<1 \mathrm{~mm}$ to a few centimetres. All fragments are elongated in about the same di- 

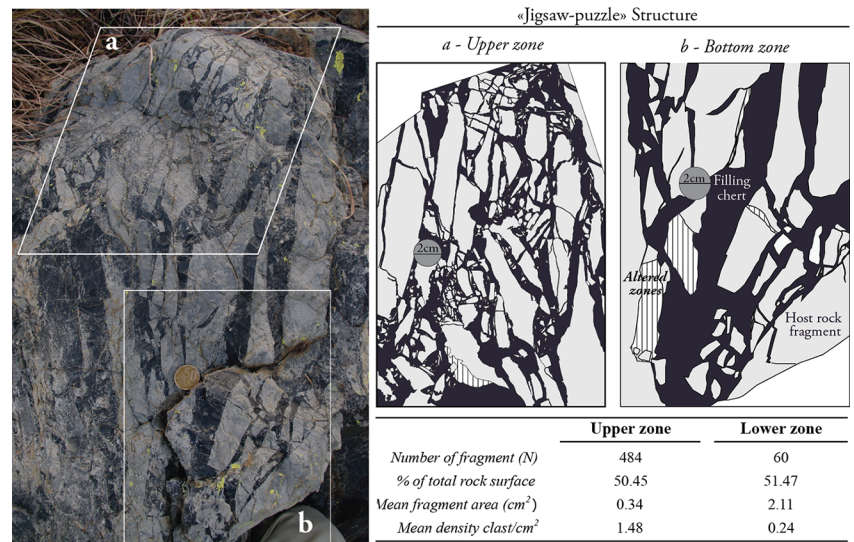

Figure 6. Highly fractured zone with jigsaw fit texture. Sketches (a, b) highlight the structures in the upper and lower zone respectively. Rocks are brecciated into small, elongated, angular and minimally displaced fragments separated by a network of thin ( $\mathrm{mm}$ to $\mathrm{cm}$ ) black chert veins. The table contains the comparative statistical analysis of the upper and lower zones. In order, we give the number of fragments $(N)$, the percentage of surface they occupy in the picture, their mean surface (representative of fragment size), and their spatial distribution expressed in density (number of clast per square centimetre). Fracturing intensity increases towards the top of the structure, where fragments are smaller and much more abundant. In the lower zone, veins are wider, showing a lack of settling of rock fragments.
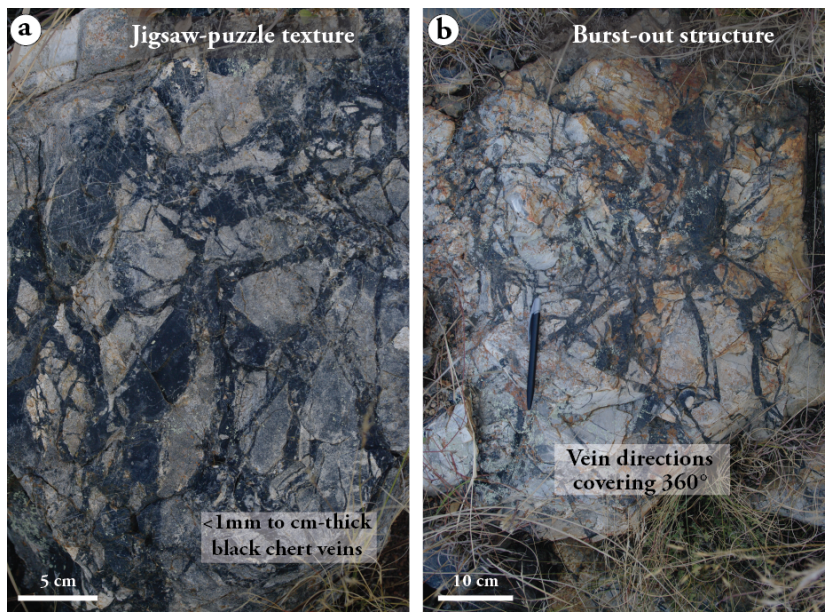

Figure 7. Hydraulic-fracturing features in Barite Valley dikes. (a) Jigsaw-puzzle texture showing in situ brecciation: angular country rock fragments are little displaced and separated by millimetre- to centimetre-thick black chert veins. (b) Randomly distributed black chert veins covering $360^{\circ}$ directions around a central, highly fractured zone.

rection, parallel to the near-vertical orientation of most of the chert veins. Figure 8d shows a typical matrix-supported dike (see Fig. $4 \mathrm{~b}$ for a larger view) in which pale blocks of country rock are suspended in the black matrix.
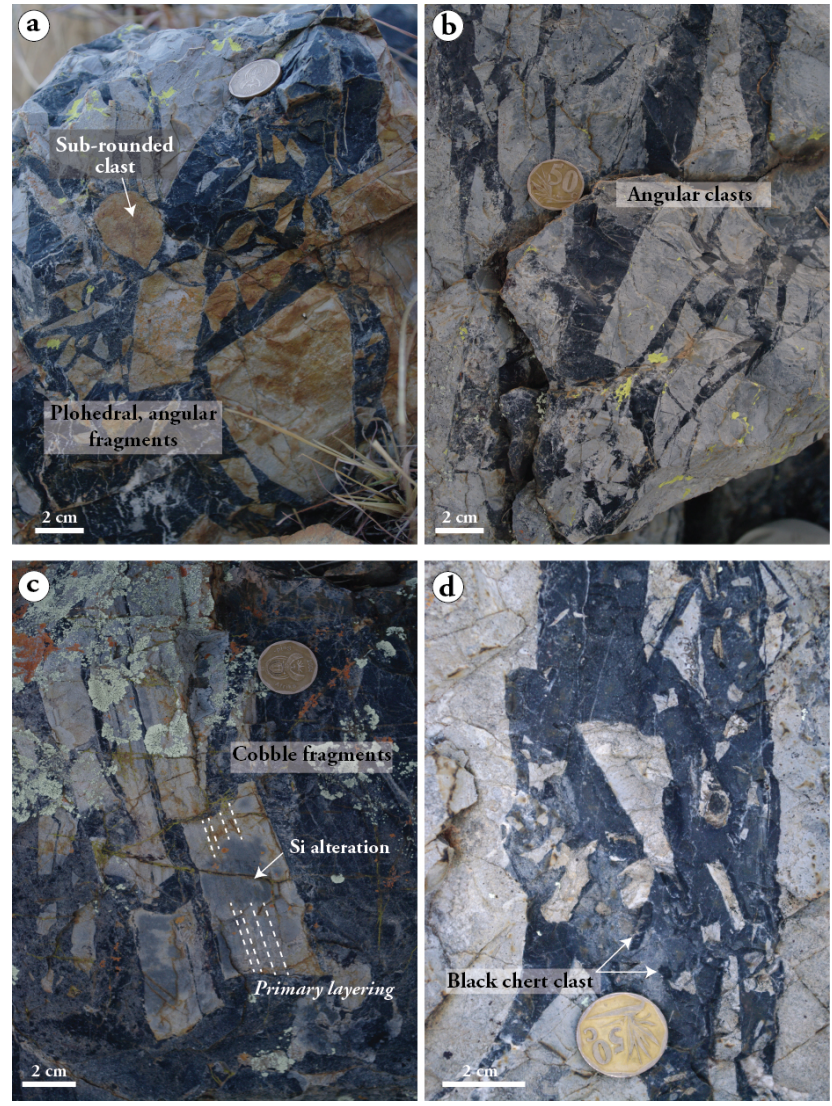

Figure 8. Selection of dikes showing the most common shapes of country rock fragments. They range in size from $<1$ to $40-50 \mathrm{~cm}$ $(<10 \mathrm{~cm}$ in average) and show a wide range of polyhedral shapes, from sub-rounded (a) to cobble-like (c), the majority being highly irregular. More than $90 \%$ of embedded fragments are from the surrounding host rock; the remaining $10 \%$ consist essentially of clasts eroded from older veins, such as the translucent black chert clasts in (d). The primary layering is generally well preserved in host rock fragments although zones of silicification can be found (c).

Clasts of black chert form a minor component (ca. 10\%) of some dikes, also suspended in the fracture-filling chert. Their textures, particularly their translucent aspect and lack of internal structures and bedding, resemble those of the black chert that fills the dikes. They are interpreted as fragments from earlier dikes that had solidified and had been brecciated during subsequent dike-forming events.

\subsection{Statistical analysis of a highly fractured zone}

We carried out a statistical analysis of the jigsaw structure shown in Fig. 6 to characterize the size, abundance and distribution of the fragments in a highly fractured zone. The outlines of the cream-coloured fragments were delineated automatically using Optimas v6.5 software and a comparison was made between the upper (a) and lower (b) zones of the dike. Because the data set has a non-Gaussian distri- 
bution (Shapiro-Wilk's test: $P<0.001 * * *$ ), classical parametric tests cannot be applied and a non-parametric test was adopted.

We found that the chert fragments fill equal areas, about $50 \%$, in the upper and lower zones (Fig. 6). However, the number and size of fragments differ significantly (KruskalWallis test: $P<0.001 * * *)$ reflecting an increasing fracture density towards the top. In the upper zone, the low average fragment size $\left(\right.$ mean $\left.=0.34 \mathrm{~cm}^{2}\right)$ is compensated by a greater number of fragments $(N=484)$. Consequently,

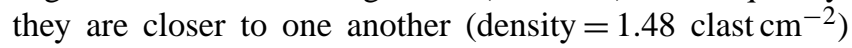
and the black matrix is restricted to a network of very fine $(<1 \mathrm{~cm})$ veins (Fig. 6a). In the lower zone the fragments are much less abundant $(N=60)$ but 6 times bigger on average $\left(\right.$ mean $\left.=2.11 \mathrm{~cm}^{2}\right)$. Their sparser distribution (density $=0.24$ clast $\mathrm{cm}^{-2}$ ) makes them appear to be suspended in the siliceous matrix, at least in the two-dimensional view of the outcrop. The fact that chert veins are wider at the bottom implies a lack of closure of the fractures and a lack of fragment settling.

\subsection{Microscopic scale: the black chert matrix}

Figure 9 illustrates the petrography of two representative fracture-filling cherts in dikes. The apparent homogeneity of the black chert at the outcrop scale does not apply at a microscopic scale. The matrix is a microbreccia consisting of small round grains $(40-80 \%)$ of silica, carbonaceous matter and minor carbonate in a very fine microquartz groundmass (20-60\%). Silica grains are the most abundant, up to $90 \%$. They are sub-angular to well rounded - almost spherical and typically are $200-300 \mu \mathrm{m}$ across (max. $1 \mathrm{~mm}$ ). They are composed of microcrystalline quartz $(<5-10 \mu \mathrm{m})$ very similar to that in the surrounding matrix, and are in sharp or diffusive contact with the surrounding components. Carbonaceous material comprises up to half the particulate fraction and consists of fine aggregates commonly $100 \mu \mathrm{m}$ in size, with rare, larger aggregates up to $500 \mu \mathrm{m}$. Carbonate grains are less abundant $(<5 \%)$ and consist of isolated, rhombohedral to rounded grains of Fe-rich dolomite $(\mathrm{MgO}=15-$ $17 \mathrm{wt} \%$; $\mathrm{FeO}=7-9 \mathrm{wt} \%$ ) (Fig. 9b).

\section{Chemical and isotopic composition}

We analysed three samples of microbreccia-type fracturefilling chert, one sample from a botryoidal textured dike, and six samples of silicified shales (two from fracture walls and four from suspended fragments) for major and trace elements at ISTerre, University of Grenoble, France (Table 1). All samples are from the MC2 unit of the Mendon Formation. Microquartz in dikes, and quartz and phyllosilicates in the country rock, were analysed by electron microprobe (Table 2). Analytical procedures are described in the Supplement.
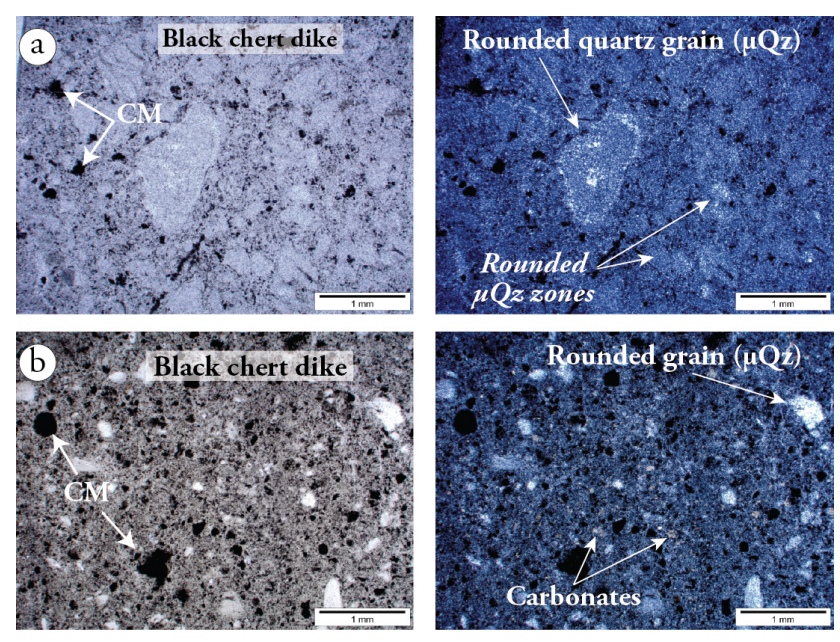

Figure 9. Photomicrographs of fracture-filling black chert samples. Left column is normal light and right column is polarized light. $\mathrm{CM}=$ carbonaceous matter; $\mathrm{mQz}=$ microquartz. (a) Sample 1 composed of rounded particles of silica and carbonaceous matter in a matrix of microquartz. The grains are $100-200 \mathrm{~mm}$ on average. Silica grains are composed of microquartz similar to the surrounding matrix leading to diffusive contact between both phases. Carbonaceous grains are aggregates of smaller particles. (b) Sample 2 composed of rounded particles of silica (50\% of the particulate fraction), carbonaceous matter $(50 \%)$ and carbonate $(<2 \%)$ in a matrix of microquartz (up to $50-60 \%$ of the chert).

\subsection{Major and trace element data}

From the microprobe analyses of Table 2, the phyllosilicates in the host rock are sericite $\left(\mathrm{SiO}_{2}=50 \mathrm{wt} \%, \mathrm{Al}_{2} \mathrm{O}_{3}=32\right.$ $34 \mathrm{wt} \%$ and $\mathrm{K}_{2} \mathrm{O}=7 \mathrm{wt} \%$ ). The coarser grains display welldefined zoning with rims depleted in $\mathrm{Na}_{2} \mathrm{O}$ but enriched in barium (4 wt \%), and to a lesser extent in $\mathrm{Cr}, \mathrm{Ti}, \mathrm{Fe}$ and $\mathrm{MgO}$.

Most host rock samples plot on mixing curves (Fig. 10) and their bulk compositions can be modelled as bimodal mixtures of $4-11 \%$ sericite and $89-96 \%$ quartz. The sericite was probably derived from clay minerals in the shale precursor and the silica (>90 wt \%) from silicification during hydrothermal alteration that preceded dike emplacement.

The compositions of the black chert that fill the dikes fall onto the same mixing curves, but closer to the quartz endmember $\left(\mathrm{SiO}_{2}>97\right.$ wt \%). Besides the dilution effect of silica, the small but significant concentrations of $\mathrm{Al}_{2} \mathrm{O}_{3}$ $(\approx 1 \mathrm{wt} \%), \mathrm{K}_{2} \mathrm{O}(\approx 0.25 \mathrm{wt} \%)$ and $\mathrm{BaO}(<0.1-0.2 \mathrm{wt} \%)$ indicate the presence of up to $4 \%$ of sericite eroded from fracture walls or derived from the hydrothermal fluid.

Trace-element contents are directly linked to the sedimentary component in the fracture-filling chert, as revealed by (1) correlations between trace elements and $\mathrm{Al}_{2} \mathrm{O}_{3}\left(r^{2}=0.85-\right.$ 0.95 for HFSE and V; $r^{2}=0.59-0.89$ for REE), and (2) similar $\mathrm{Zr} / \mathrm{Hf}$ ratios in the host rock (39-47) and dike (3948) (Table 1). Chromium contents are higher in the dike 
Table 1. Major and trace element analyses of Barite Valley silicified shales and fracture-filling cherts $(<1 . d .=$ below detection limit; n.a. $=$ not analysed).

\begin{tabular}{|c|c|c|c|c|c|c|c|c|c|c|}
\hline \multirow[b]{3}{*}{$(\mathrm{wt} \%)$} & \multicolumn{6}{|c|}{ Silicified country rock } & \multicolumn{4}{|c|}{ Fracture-filling chert } \\
\hline & \multicolumn{2}{|c|}{ Fracture wall } & \multicolumn{4}{|c|}{ Fragments in dikes } & \multicolumn{3}{|c|}{ Microbreccia-type } & \multirow{2}{*}{$\begin{array}{r}\text { Botryoidal silica } \\
\text { FTC17 }\end{array}$} \\
\hline & FTC1A & FTC2A & FTC1B & FTC2B & FTC4A & FTC4B & FTC2-C1 & FTC2-C2 & FTC4-BC & \\
\hline $\mathrm{SiO}_{2}$ & 94.08 & 94.88 & 94.40 & 96.19 & 91.47 & 90.74 & 97.80 & n.a. & 97.07 & n.a. \\
\hline $\mathrm{TiO}_{2}$ & $<$ l.d. & 0.07 & $<1 . d$ & 0.07 & 0.13 & 0.12 & $<1 . d$ & n.a. & $<$ l.d. & n.a. \\
\hline $\mathrm{Al}_{2} \mathrm{O}_{3}$ & 1.23 & 1.74 & 1.49 & 2.38 & 3.86 & 3.69 & 1.24 & n.a. & 0.83 & n.a. \\
\hline $\mathrm{Fe}_{2} \mathrm{O}_{3} t$ & 0.53 & 0.26 & 0.74 & 0.65 & 0.36 & 0.35 & 0.22 & n.a. & 0.23 & n.a. \\
\hline $\mathrm{MnO}$ & $<1 . d$ & $<$ l.d. & $<$ l.d. & $<$ l.d. & $<$ l.d. & $<1 . d$ & $<$ l.d. & n.a. & 0.01 & n.a. \\
\hline $\mathrm{MgO}$ & $<1 . d$ & $<$ l.d. & $<1 . d$ & $<$ l.d. & $<$ l.d. & $<1 . d$ & $<$ l.d. & n.a. & $<1 . d$ & n.a. \\
\hline $\mathrm{CaO}$ & $<1 . d$ & $<$ l.d. & $<1 . d$ & $<$ l.d. & $<$ l.d. & $<1 . d$ & $<$ l.d. & n.a. & 0.25 & n.a. \\
\hline $\mathrm{Na}_{2} \mathrm{O}$ & 0.03 & 0.03 & 0.03 & $<$ l.d. & 0.04 & 0.04 & $<$ l.d. & n.a. & 0.02 & n.a. \\
\hline $\mathrm{K}_{2} \mathrm{O}$ & 0.26 & 0.36 & 0.30 & 0.44 & 0.84 & 0.80 & 0.26 & n.a. & 0.21 & n.a. \\
\hline $\mathrm{Cr}_{2} \mathrm{O}_{3}$ & 0.002 & 0.01 & 0.002 & $<1 . d$. & 0.01 & 0.01 & $<$ l.d. & n.a. & $<1 . d$ & n.a. \\
\hline LOI & 0.64 & 0.67 & 0.72 & 0.66 & 0.98 & 0.98 & 0.67 & n.a. & 1.15 & n.a. \\
\hline $\begin{array}{l}\text { Somme } \\
\text { (ppm) }\end{array}$ & 96.78 & 98.03 & 97.69 & 100.39 & 97.68 & 96.74 & 100.19 & n.a. & 99.78 & n.a. \\
\hline $\mathrm{Cs}$ & 0.322 & 0.337 & 0.315 & 0.376 & 0.635 & 0.625 & 0.346 & 0.355 & 0.443 & 0.071 \\
\hline $\mathrm{Rb}$ & 9.56 & 14.3 & 11.2 & 23.1 & 34.9 & 34.1 & 12.4 & 12.2 & 7.24 & 0.085 \\
\hline $\mathrm{Ba}$ & 1659 & 2366 & 1964 & 2442 & 4466 & 4356 & 1807 & 1817 & 728 & 300 \\
\hline $\mathrm{Th}$ & 0.715 & 1.04 & 0.804 & 1.37 & 2.76 & 2.67 & 0.701 & 0.704 & 0.583 & $<1 . d$. \\
\hline $\mathrm{U}$ & 0.227 & 0.309 & 0.257 & 0.368 & 0.718 & 0.684 & 0.247 & 0.249 & 0.201 & 0.092 \\
\hline $\mathrm{Nb}$ & 0.823 & 1.18 & 0.924 & 2.05 & 3.04 & 2.97 & 1.02 & 1.06 & 0.621 & 0.006 \\
\hline $\mathrm{Ta}$ & 0.087 & 0.107 & 0.096 & 0.163 & 0.273 & 0.261 & 0.045 & 0.071 & 0.073 & $<1$. d. \\
\hline $\mathrm{Pb}$ & 0.786 & 1.80 & 1.11 & 2.13 & 1.29 & 1.26 & 1.56 & 1.55 & 1.38 & $<$ l.d. \\
\hline $\mathrm{Sr}$ & 5.68 & 7.22 & 6.49 & 7.22 & 4.89 & 4.80 & 9.84 & 10.0 & 6.17 & 1.89 \\
\hline $\mathrm{Zr}$ & 11.4 & 16.1 & 14.5 & 27.1 & 34.2 & 33.4 & 13.3 & 13.5 & 7.33 & 0.543 \\
\hline $\mathrm{Hf}$ & 0.293 & 0.406 & 0.365 & 0.573 & 0.838 & 0.844 & 0.277 & 0.282 & 0.184 & $<$ l.d. \\
\hline $\mathrm{Ti}$ & 245 & 411 & 278 & 542 & 749 & 738 & 334 & 333 & 206 & 0.545 \\
\hline $\mathrm{Li}$ & 0.642 & 1.10 & 0.629 & 1.83 & 1.75 & 1.74 & 0.709 & 0.72 & 0.829 & $<1 . d$ \\
\hline $\mathrm{Sc}$ & 1.78 & 1.76 & 2.28 & 2.51 & 3.44 & 3.34 & 1.34 & 1.38 & 1.01 & $<$ l.d. \\
\hline V & 9.90 & 15.3 & 12.2 & 20.3 & 24.2 & 24.2 & 13.2 & 13.1 & 7.03 & 0.175 \\
\hline $\mathrm{Cr}$ & 44.9 & 82.1 & 50.4 & 98.2 & 107 & 106 & 75.9 & 76.5 & 29.2 & 18.2 \\
\hline Co & 27.3 & 26.1 & 35.0 & 1.56 & 17.0 & 16.8 & 4.04 & 4.06 & 65.5 & $<$ 1.d. \\
\hline $\mathrm{Ni}$ & 24.3 & 17.7 & 37.6 & 21.1 & 21.8 & 21.5 & 22.5 & 22.6 & 18.6 & 1.48 \\
\hline $\mathrm{Cu}$ & 5.08 & 13.2 & 7.00 & 12.3 & 5.61 & 5.59 & 17.4 & 17.4 & 4.35 & 0.445 \\
\hline $\mathrm{Zn}$ & 3.11 & 11.0 & 4.27 & 8.60 & 6.67 & 6.53 & 14.0 & 13.9 & 4.27 & $<1 . d$ \\
\hline As & 3.68 & 16.6 & 4.17 & 17.2 & 17.8 & 17.4 & 10.4 & 10.4 & 9.24 & 0.211 \\
\hline $\mathrm{La}$ & 5.26 & 10.2 & 7.19 & 7.68 & 7.94 & 7.7 & 5.22 & 5.17 & 1.59 & 0.033 \\
\hline $\mathrm{Ce}$ & 5.66 & 11.2 & 7.12 & 9.18 & 12.9 & 12.6 & 5.98 & 5.88 & 3.06 & 0.062 \\
\hline $\operatorname{Pr}$ & 1.37 & 2.11 & 1.91 & 1.56 & 1.7 & 1.62 & 1.07 & 1.08 & 0.379 & 0.008 \\
\hline $\mathrm{Nd}$ & 5.51 & 6.63 & 7.61 & 4.82 & 5.78 & 5.57 & 3.33 & 3.31 & 1.41 & 0.032 \\
\hline $\mathrm{Sm}$ & 1.02 & 1.08 & 1.41 & 0.817 & 0.915 & 0.884 & 0.548 & 0.507 & 0.286 & $<$ 1.d. \\
\hline $\mathrm{Eu}$ & 0.227 & 0.242 & 0.307 & 0.187 & 0.273 & 0.256 & 0.121 & 0.105 & 0.073 & $<$ l.d. \\
\hline $\mathrm{Gd}$ & 0.892 & 0.755 & 1.180 & 0.656 & 0.987 & 0.919 & 0.394 & 0.386 & 0.342 & 0.027 \\
\hline $\mathrm{Tb}$ & 0.111 & 0.093 & 0.151 & 0.095 & 0.134 & 0.130 & 0.050 & 0.052 & 0.046 & 0.003 \\
\hline Dy & 0.600 & 0.509 & 0.798 & 0.649 & 0.867 & 0.797 & 0.294 & 0.297 & 0.284 & 0.031 \\
\hline Ho & 3.150 & 2.630 & 3.870 & 4.400 & 4.870 & 4.760 & 1.920 & 1.930 & 1.790 & 0.283 \\
\hline $\mathrm{Y}$ & 0.108 & 0.0937 & 0.142 & 0.126 & 0.173 & 0.169 & 0.0544 & 0.0581 & 0.0561 & 0.007 \\
\hline $\mathrm{Er}$ & 0.3 & 0.259 & 0.362 & 0.381 & 0.528 & 0.501 & 0.153 & 0.154 & 0.17 & 0.024 \\
\hline $\mathrm{Yb}$ & 0.25 & 0.239 & 0.304 & 0.345 & 0.559 & 0.539 & 0.155 & 0.151 & 0.178 & 0.020 \\
\hline $\mathrm{Lu}$ & 0.037 & 0.033 & 0.042 & 0.052 & 0.078 & 0.079 & 0.022 & 0.021 & 0.025 & 0.004 \\
\hline$\Sigma \mathrm{REE}$ & 24.49 & 36.07 & 32.40 & 30.95 & 37.70 & 36.52 & 19.31 & 19.10 & 9.69 & 0.53 \\
\hline $\mathrm{Zr} / \mathrm{Hf}$ & 38.91 & 39.66 & 39.73 & 47.29 & 40.81 & 39.57 & 48.01 & 47.87 & 39.84 & \\
\hline $\mathrm{Th} / \mathrm{Sc}$ & 0.40 & 0.59 & 0.35 & 0.55 & 0.80 & 0.80 & 0.52 & 0.51 & 0.58 & \\
\hline
\end{tabular}


Table 2. In situ microprobe analyses of various components in Barite Valley fracture-filling cherts and surrounding silicified shales $(\mathrm{SD}=$ standard deviation).

\begin{tabular}{lcr|rrrrrr}
\hline & \multicolumn{2}{c|}{ Fracture-filling chert } & \multicolumn{5}{c}{ Siliceous, sericite-rich shale (hostrock) } \\
\cline { 2 - 9 }$(\mathrm{wt} \%)$ & \multicolumn{2}{c}{ Quartz } & & \multicolumn{2}{c}{ Sericite core } & Sericite rim & \multicolumn{2}{c}{ Quartz } \\
\cline { 2 - 9 } & $n=40$ & $\mathrm{SD}$ & $n=6$ & $\mathrm{SD}$ & $n=5$ & $\mathrm{SD}$ & $n=7$ & $\mathrm{SD}$ \\
\hline $\mathrm{SiO}_{2}$ & 99.1 & 0.57 & 50.2 & 1.05 & 47.6 & 0.99 & 98.2 & 2.22 \\
$\mathrm{Al}_{2} \mathrm{O}_{3}$ & 0.16 & 0.13 & 34.21 & 1.70 & 32.38 & 0.49 & 0.25 & 0.11 \\
$\mathrm{~K}_{2} \mathrm{O}$ & 0.02 & 0.03 & 7.64 & 1.25 & 7.04 & 0.65 & 0.04 & 0.03 \\
$\mathrm{Na}_{2} \mathrm{O}$ & 0.01 & 0.01 & 0.37 & 0.33 & 0.09 & 0.01 & $<0.01$ & \\
$\mathrm{MgO}$ & 0.00 & 0.01 & 1.01 & 0.37 & 1.55 & 0.23 & $<0.02$ & \\
$\mathrm{CaO}$ & 0.01 & 0.01 & $<0.01$ & & $<0.01$ & & $<0.02$ & \\
$\mathrm{FeO}$ & 0.03 & 0.02 & 1.04 & 0.61 & 1.24 & 0.91 & 0.40 & 0.96 \\
$\mathrm{MnO}$ & 0.01 & 0.01 & 0.01 & 0.01 & 0.01 & 0.01 & $<0.02$ & \\
$\mathrm{TiO}_{2}$ & 0.01 & 0.03 & 0.20 & 0.07 & 0.29 & 0.07 & 0.02 & \\
$\mathrm{Cr}_{2} \mathrm{O}_{3}$ & 0.01 & 0.01 & 0.07 & 0.04 & 0.14 & 0.02 & 0.01 & 0.02 \\
$\mathrm{P}_{2} \mathrm{O}_{5}$ & 0.01 & 0.01 & 0.01 & 0.01 & 0.02 & 0.02 & $<0.01$ & \\
$\mathrm{BaO}$ & 0.07 & & 0.68 & & 4.07 & & 0.09 & \\
$\mathrm{NiO}_{\mathrm{Total}}$ & 0.00 & 0.01 & 0.01 & 0.01 & 0.01 & 0.02 & 0.01 & 0.02 \\
& 99.5 & & 95.5 & & 94.4 & & 99.0 & \\
\hline
\end{tabular}
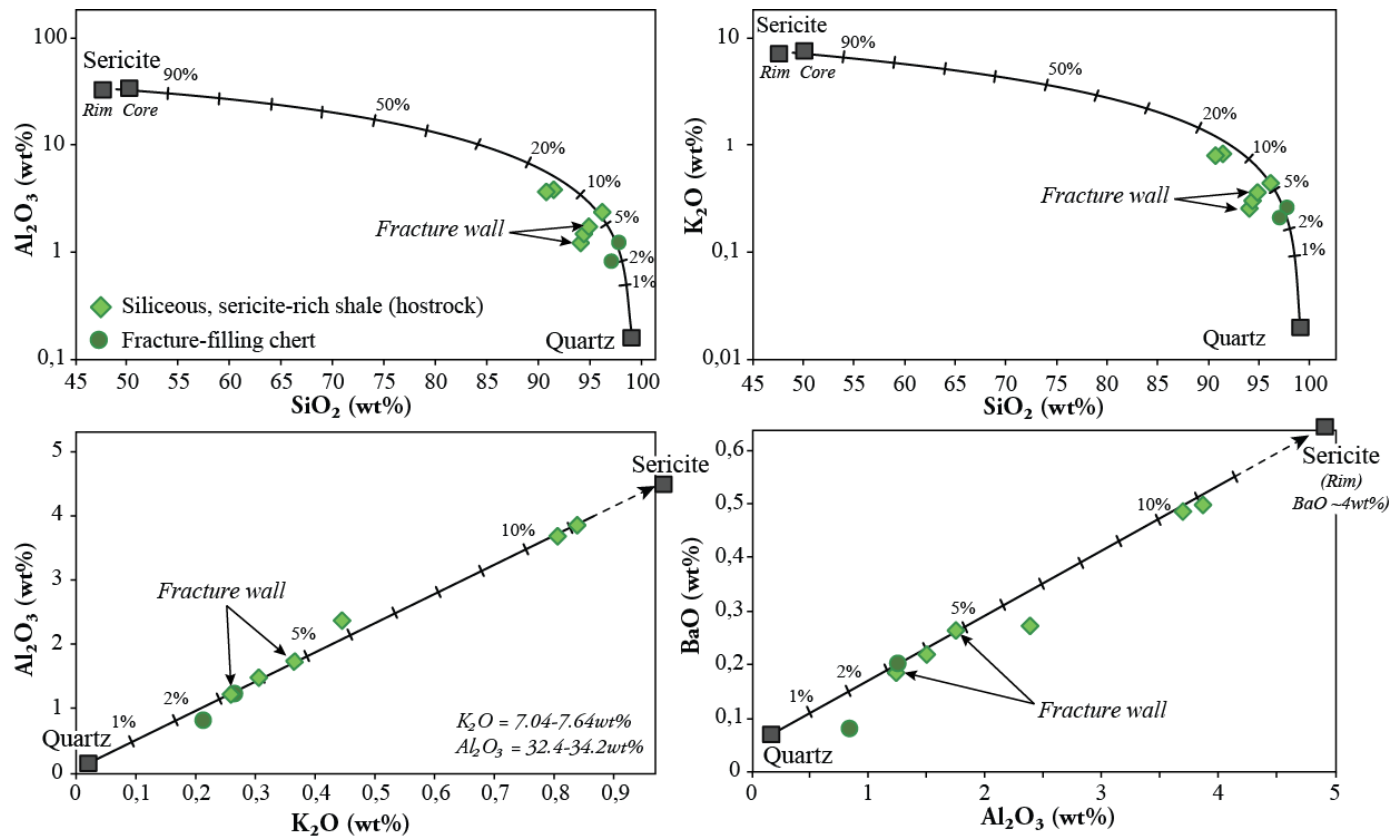

Figure 10. Major element correlation diagrams showing (1) decreasing aluminium and potassium concentrations with increasing $\mathrm{SiO}_{2}$, and (2) positive correlations between aluminium, potassium and barium. All samples fall on correlation lines between sericite and quartz, whose composition was obtained in situ by microprobe analysis. These data indicate that $<4 \%$ of sericite is enough to control the fracture-filling chert chemistry.

$(\mathrm{Cr} / \mathrm{Th}=50-109)$ than the country rock (39-79), suggesting a contribution from other, unidentified components.

On the basis of their mineralogy and geochemistry, the black chert filling Barite Valley dikes are interpreted as mixtures of (1) carbonaceous and silica particles of uncertain origin, (2) sericite from host rocks, and (3) silica that forms most of the groundmass.

The chemical composition of the groundmass is of particular interest because it could have recorded the characteristics of the fluid that circulated through the dikes. However, their bulk chemistry is strongly influenced by minor amounts of 
material from the host rocks and only very pure chert with extremely low trace element contents have a chance to preserve the composition of the primary siliceous precipitate. Botryoidal silica from the late-stage dike (Fig. 5a) meets this requirement: the total REE content is about $0.5 \mathrm{ppm}$ and a sericite contribution can be ruled out on the basis of extremely low HFSE $(\mathrm{Zr}=0.54 \mathrm{ppm})$ and barium $(<270 \mathrm{ppm})$ contents. The shale-normalized pattern (Fig. 11) reveals strong depletion in LREE $\left(\operatorname{Pr} / \mathrm{Yb}_{\mathrm{SN}}=0.12\right)$, enrichment in $\mathrm{Y}(\mathrm{Y} / \mathrm{Ho}=39.3)$ and positive lanthanum $\left(\mathrm{La} / \mathrm{La}^{*}=1.36\right)$ and gadolinium $\left(\mathrm{Gd} / \mathrm{Gd}^{*}=4.76\right)$ anomalies. It is not clear, however, whether the fluid that formed this late-stage dike was identical to the one that formed the earlier fragmentfilled black chert dikes.

\subsection{Isotopic data}

Silicon and oxygen isotopic compositions were measured in situ in two samples using the CAMECA IMS1280 ion microprobe at CRPG (Nancy, France): (1) a black chert with microbreccia matrix (sample FTC4, Fig. 9), and (2) botryoidal silica (sample FTC17, Fig. 5a). The analytical procedure is described in the Supplement. Results are given using the delta notation and expressed as probability density functions in Fig. 12.

$\delta^{30} \mathrm{Si}$ of the microbreccia varies widely, from -4.50 to $-0.19 \%$ with a mean value of $-1.37 \pm 0.22 \%$. The distribution is irregular with major peaks at -1 and $-2 \% o$, and minor peaks at -3.3 and $-4.5 \%$. The botryoidal silica has a mean $\delta^{30} \mathrm{Si}$ of $-0.91 \pm 0.32 \%$ and a more restricted range from -1.89 up to $+0.22 \%$. The latter value is limited to a single analysis.

The $\delta^{18} \mathrm{O}$ in these samples have a very narrow range of less than $1 \%$. The botryoidal silica has a surprisingly high mean $\delta^{18} \mathrm{O}$ of $23.68 \pm 0.34 \%$ and the microbreccia has a mean at $20.97 \pm 0.11 \%$ 。

\section{Discussion}

\subsection{Fracturing process}

Two main theories have been proposed to explain the formation of Barite Valley dikes, both based on extensive field mapping, analysis of dike geometry and structure, and petrographic observations. Hofmann and Bolhar (2007) advocate hydraulic fracturing. According to them, pervasive and diffuse circulation of low-temperature hydrothermal fluids through the seafloor silicified the sedimentary units of the Upper Mendon Formation during or just after deposition. The resulting impermeable cap of chert acted as a seal and increasing pressure in trapped fluids led to hydraulic fracturing and dike formation. Lowe and Byerly (2003) and Lowe (2013) proposed that a meteorite impact shattered the ocean crust and that unconsolidated carbonaceous sediments present at the seafloor subsequently filled the fractures.

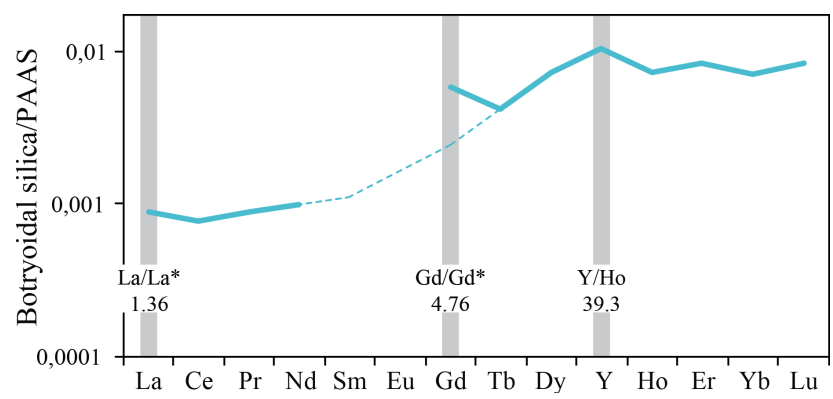

Figure 11. Shale-normalized (PAAS; Taylor and McLennan, 1985) REE pattern for the pure, botryoidal silica sample of Fig. 5a showing seawater-like characteristics. Sm and Eu are below the detection limit. We calculate their theoretical concentrations using that of their neighbouring elements (Sm using Pr and Nd, and Eu using $\mathrm{Sm}$ and Gd). Because of its anomalous enrichment, a theoretical $\mathrm{Gd}$ concentration is also modelled using $\mathrm{Tb}$ and $\mathrm{Dy}$. The resulting dotted line helps to highlight the LREE depletion trend typical of oceanic fluids.

The two hypotheses imply different directions of fluid flow within the fractures; dominantly upward in the hydraulic fracturing model and downward in the meteorite impact model. Hofmann and Bolhar (2007) and Lowe (2013) both consider that the fractures were at least partly filled from above with unconsolidated carbonaceous sediment. The main arguments are (1) the presence in some dikes of rock fragments from higher stratigraphic levels (e.g. spherules from S2; Fig. 1), (2) downward displacement of blocks from adjacent country rocks, (3) carbonaceous matter in the cherts that originated from biogenic processes on or near the ocean floor, and (4) the geometry of the entire dike complex, which reaches a maximum width of $50 \mathrm{~m}$ at the top and narrows downward in the Mendon volcanic units.

Although we concur with most of these observations and interpretations, several key structures indicate that fluid migration was dominantly upward.

1. Figure 13a shows a dike-and-sill structure similar to those in magmatic conduits (e.g. Gudmundsson, 2011 and references therein) and in sand injectite complexes (e.g. Thompson et al., 2007; Braccini et al., 2008). The main, vertical channel spreads out laterally along weaker sedimentary intervals to form horizontal veins (or sills). The structure does not persist upward but ends with a final sill of limited lateral extent $(<40 \mathrm{~cm})$. In both sedimentary and magmatic settings, such structures are attributed to upward injection of overpressured fluids, either magma or fluidized sand (e.g. Thompson et al., 2007; Gudmundsson, 2011; Maccaferri et al., 2011).

2. The main feeder channel of the multi-branch dike in Fig. 13a narrows upward, supporting an ascending movement of the fluid. 

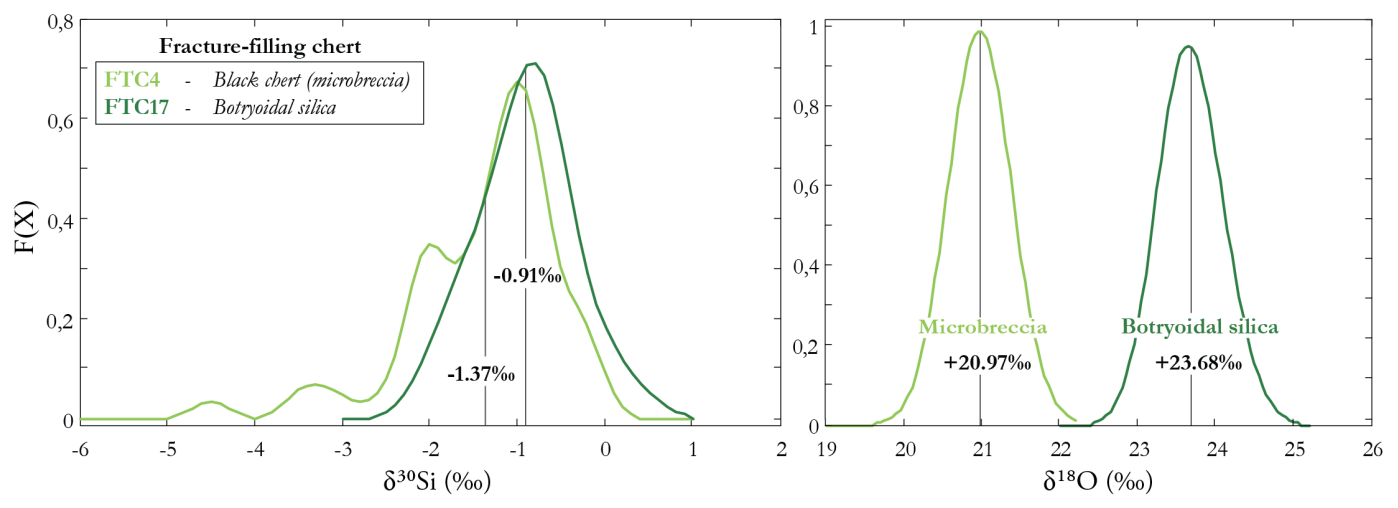

Figure 12. Probability density function showing the distribution of in situ single-grain isotopic composition (oxygen and silicon) within one microbreccia sample (FTC4, light green) and one botryoidal silica sample (FTC17, dark green). Values in black are mean $\delta^{30} \mathrm{Si}$ and $\delta^{18} \mathrm{O}$. Note the various peaks observed in the negative region for the microbreccia.
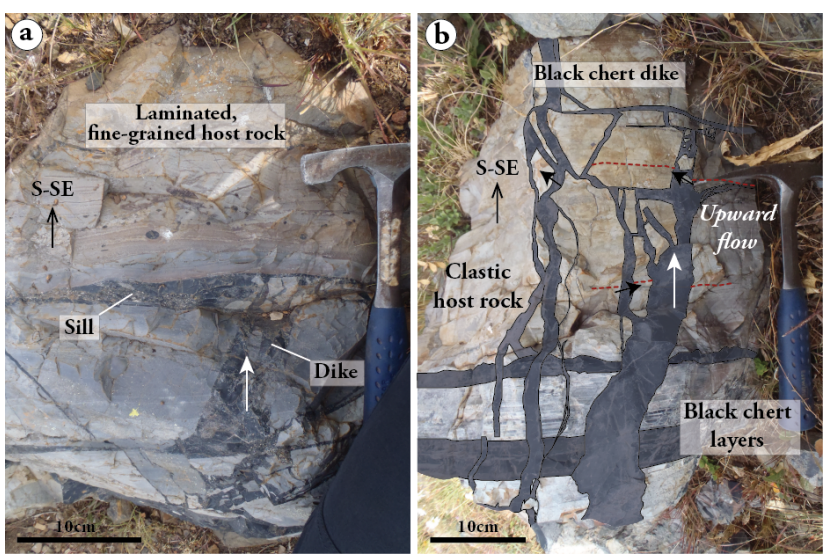

Figure 13. (a) Dike-and-sill structure: a central, vertical channel spreads out laterally along weak sedimentary plane to produce sills concordant with country rock bedding. The structure ends at the top by a final, $<5 \mathrm{~cm}$ thick sill. (b) Vertical dike narrowing in the younging direction. Black arrows indicate displacement $(\sim 1 \mathrm{~cm})$ towards the top of the vein. Both photos are evidence for a migration of fluids from below (white arrow).

3. The central part of the dike contains suspended host rock fragments that were displaced upwards for small distances $(\sim 1 \mathrm{~cm}$; black arrows in Fig. 13b). Hofmann and Bolhar (2007) also reported significant upward displacement of komatiite clasts from lower stratigraphic levels.

Another series of observations argues that hydraulic fracturing shattered the rocks.

1. The presence of mosaic breccias with distinctive jigsaw puzzle textures, the angularity of the fragments, and the lack of significant movement or rotation are diagnostic of hydraulic fracturing according to the criteria summarized by Jebrak (1997).
2. The abundance of highly shattered zones and multiple injection features in certain dikes suggest the involvement of high-pressure fluids (Jobson et al., 1994; Jebrak, 1997; Li et al., 2002).

3. The statistical analysis of the jigsaw-patterned dike (Fig. 6, Sect. 2.4) reveals an increase of fracture density towards the top of the structure, also supporting a role of high-pressure fluids from below. The lack of settling of matrix-supported blocks (e.g. Fig. 4b), and the lack of closure of the fracture networks further support this idea because the veins would have closed if not kept open by overpressured fluids.

4. Additional characteristics, although less diagnostic, include the restricted size range of suspended fragments (Jebrak, 1997), the homogeneity of the filling material (Jebrak, 1997), the high matrix-to-fragments ratio in some dikes, the sharpness of contacts between dikes and country rocks ( $\mathrm{Li}$ et al., 2002), and the random orientation of parts of the vein network (Marone and Scholtz, 1989; Li et al., 2002).

\subsection{Origin of the fluid(s) and temperature of the system}

Botryoidal silica in the late dikes provides the best record of fluid composition. Its composition (Table 1, Fig. 11) shares key characteristics with modern seawater, such as the strong depletion in LREE and positive La, Gd and Y anomalies (see Bolhar et al., 2004, for a review of such proxies). Accordingly, evolved seawater must have circulated through the system, at least through the late-stage fractures.

The $\mathrm{Si}$ and $\mathrm{O}$ isotopic compositions of the fracture-filling cherts may be more diagnostic (e.g. Marin et al., 2010; Van den Boorn et al., 2010). Oxygen isotopes register the fluid temperatures (e.g. Perry and Lefticariu, 2003; MarinCarbonne et al., 2012) and silicon isotopes provide information about the nature of the fluid (e.g. André et al., 2006). 
The strongly negative $\delta^{30} \mathrm{Si}$ values $(-1.37 \pm 0.22 \%$ o of groundmass silica in chert dikes (sample FT4) resemble values in modern hydrothermal deposits such as in siliceous sinter $\left({ }^{30} \mathrm{Si}_{\text {average }}=-1.4 \%\right.$; Douthitt, 1982), and submarine siliceous sediments produced by black smokers $\left(\delta^{30} \mathrm{Si}_{\text {average }}=-1.56 \%\right.$ with values down to $-3.5 \%$; Jiang et al., 1997, André et al., 2006). The different peaks in Fig. 12 indicate fluids with contrasting compositions (MarinCarbonne et al., 2012), but most of the data are within the $-1 \%$ peak. Accepting a fractionation value of $-1 \%$ o between dissolved and precipitated silica (De La Rocha et al., 1997; Ding et al., 2004), the precipitating fluid would have had a $\delta^{30} \mathrm{Si}$ around $0 \%$. This value is consistent with hydrothermal fluid that equilibrated with mafic to ultramafic rocks (De La Rocha et al., 2000; André et al., 2006). In line with the significant $\mathrm{Cr}$ enrichment in our samples (Sect. 3.1), we believe that the fluid acquired its near-zero $\delta^{30} \mathrm{Si}$ in the komatiitic units of the Mendon Formation before being injected upwards into the dike system.

The botryoidal silica dike has a narrower range of values around a slightly less negative mean $\delta^{30} \mathrm{Si}$ of $-0.91 \pm 0.32 \%$. The single Gaussian distribution of the data suggests the precipitation of microquartz from a homogeneous reservoir. Applying the same fractionation factor, we calculate an initial $\delta^{30} \mathrm{Si}_{\text {Fluid }}$ of $0.09 \%$ o. However, this value may be an underestimate in view of the conclusion of $\mathrm{Li}$ et al. (1995): "the lower the exhalative temperature and the slower the precipitation rate of $\mathrm{SiO}_{2}$, the lower the $\delta^{30} \mathrm{Si}$ values will be". The botryoidal or colloform textures (Fig. 6) indicate low precipitation temperatures and a slow kinetic of silica precipitation. Accordingly, the present $\delta^{30} \mathrm{Si}_{\text {Fluid }}$ would shift toward more positive values, approaching the composition expected for Precambrian seawater (up to $+1.3 \%$ according to Van den Boorn et al., 2010).

For both these chert dikes, the oxygen isotopic composition is restricted to a narrow range of less than $1 \%$ (Fig. 12), which would indicate complete resetting of the system according to the preservation criterion of Marin-Carbonne et al. (2012). However, the preservation of botryoidal silica and chalcedony in some dikes indicates temperatures below $200^{\circ} \mathrm{C}$, which is incompatible with the active dissolution and precipitation of quartz required for a complete reset of oxygen isotopes. Accordingly, we propose that the following temperatures are those of fluids that circulated and precipitated silica in the dikes.

The temperature can be approximated using the equation of Knauth and Epstein (1975):

$$
\begin{aligned}
1000 \ln \alpha & =3.09 \times\left(10^{6} / T^{2}\right)-3.29 \\
\text { with } \alpha & =\left(1000+\delta^{18} \mathrm{O}_{\text {Sample }}\right) /\left(1000+\delta^{18} \mathrm{O}_{\text {Fluid }}\right)
\end{aligned}
$$

Because of the oceanic signal preserved in the botryoidal silica, we use a $\delta^{18} \mathrm{O}_{\text {Fluid }}$ of +0.4 to $+2.1 \%$, which is the range covered by Precambrian hydrothermal fluids derived from seawater (De Ronde and de Wit, 1994; Channer et al.,
1997). In agreement with the extremely high $\delta^{18} \mathrm{O}_{\mathrm{FTC17}}$ of $\sim 23.7 \%$, the botryoidal silica precipitated at a very low temperature of 60 to $80^{\circ} \mathrm{C}$. In the microbreccia dike, the presence of strongly negative $\delta^{30} \mathrm{Si}$ peaks may indicate a contribution from more evolved seawater. Lécuyer et al. (1994) reported $\delta^{18} \mathrm{O}_{\text {Fluid }}$ of $+6 \%$ for metamorphic fluids that reacted with komatiites, a value that gives a precipitation temperature of $130-140{ }^{\circ} \mathrm{C}$.

From the trace element and isotopic data, we conclude that modified seawater circulated at low temperature within the whole system. It interacted at depth with komatiitic units before being ejected upwards at moderate temperatures $\left(<150^{\circ} \mathrm{C}\right)$. Over-pressured fluid shattered silicified sediments and precipitated silica in the resulting fractures. During quiet periods, less modified, low-temperature fluid penetrated the crust and precipitated silica in open fractures. The Barite Valley dikes are thus relicts of a low-temperature, shallow-level hydrothermal system.

\subsection{Rheological behaviour of the circulating fluids}

In Sect. 2.3, we showed several examples where black chert invaded a dense network of fractures and penetrated even the finest $(<1 \mathrm{~mm})$ veins. This indicates that the filling material had low viscosity at the time it was injected. In contrast, very soon after injection, the same material acquired a viscosity high enough to suspend large blocks of country rock. Although the pressure exerted by the fluid during hydraulic fracturing can support fragments at first, we argue that a significant increase of the viscosity is required as pressure is released. Such a transition from "pressure-supported" to "viscosity-supported" must have been sufficiently rapid that the fragments had no time to settle towards the lower part of the fractures. In other words, the filling material exhibited viscoelastic, shear-thinning behaviour, and most probably thixotropy (e.g. Bauer and Collins, 1967; Barnes, 1997; Amiri et al., 2009; Mewis and Wagner, 2009). In the following sections, we investigate the cause of such behaviour and offer a dynamic view of the fracture infilling process.

\subsubsection{The cause of shear thinning and thixotropic behaviour}

At all scales, the filling material in Barite Valley dikes can be described as a mixture of solid fragments initially suspended in a liquid medium. At the outcrop scale (Fig. 14, top), host-rock fragments are suspended in a now consolidated black chert matrix. At a micrometre scale (Fig. 14, middle), the chert matrix is seen to have been a slurry of fine, rounded solid particles of silica and carbonaceous material in a solution of colloidal silica. At a nanometre scale (Fig. 14, bottom), the colloidal solution itself was composed of silica flocs suspended in a seawater-derived hydrothermal fluid. After injection, the whole system consolidated to its 
PARTICULATE FRACTION

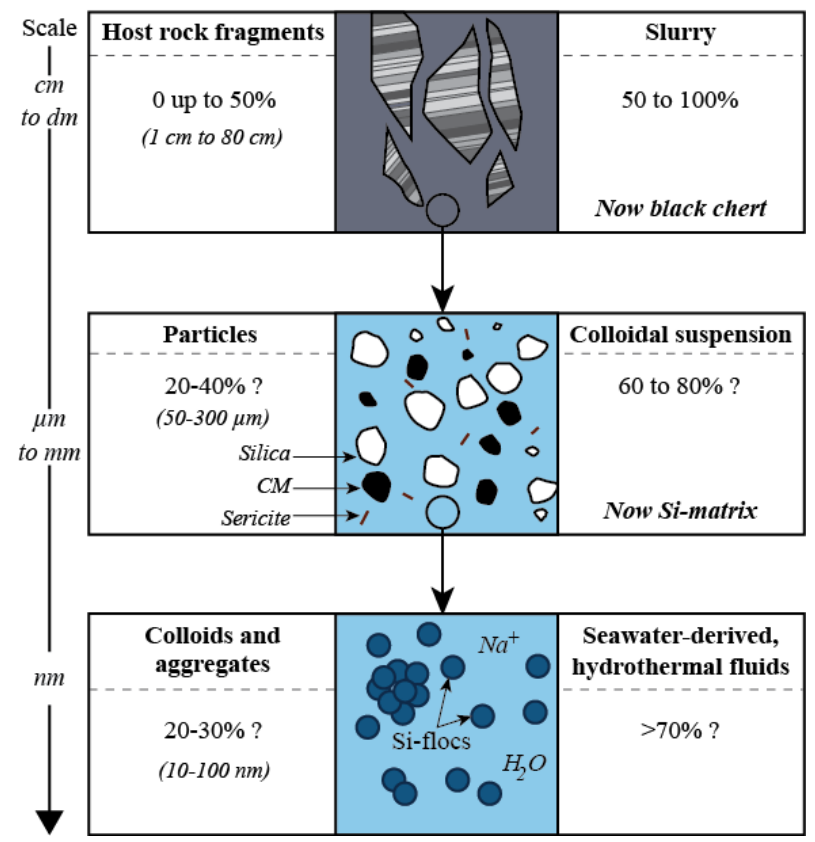

Figure 14. Sketches showing our interpretation of the chert properties at the time of injection and at various scales. From top to bottom, the chert consistently contained a "particulate" and a "liquid" fraction in varying proportions. Percentages are approximate, i.e. based on thin section observations and taking into account the dewatering and compaction of cherts during induration. The colloidal fraction (bottom) is responsible of the rapid viscosity variations through gelation.

present cherty state through well-known silica precipitation, dewatering and volume loss processes (e.g. Knauth, 1994).

The nano- and micro-textures of the slurry are particularly relevant. Barnes (1997) and Mewis and Wagner (2009 and references therein) reported that viscoelasticity, and especially thixotropy, is commonly observed in colloidal fluids or other systems in which solid particles are suspended in a fluid (e.g. pharmaceutical products, food products, adhesives, paints). Clay and silicate slurries and suspensions used in the mining industry are also subject to strong viscosity variations under varying shear stresses and rates (e.g. Nguyen and Boger, 1985; Besq et al., 2000; Oleksy et al., 2007).

Although the exact cause of viscosity variations in natural systems is debated, it is broadly accepted that their rheological behaviour is controlled by competition between (1) the break-down of particle-particle interactions and microstructures in the fluid under flow stresses, and (2) the build-up of new interactions and microstructures promoted by van der Waals and electrostatic attractive forces, in-flow collisions and Brownian motion (e.g. Boswell, 1948; Barnes, 1997; Mewis and Wagner, 2009). These interactions are controlled by numerous parameters, including those listed below.
1. Abundance of the particulate fraction (Jeffrey and Acrivos, 1976; Yanez et al., 1999; Di Giuseppe et al., 2012). It is now widely accepted that any suspension containing a sufficient quantity of hard particles can exhibit shear-thinning behaviour (e.g. Barnes, 1997; Stickel and Powell, 2005; Mewis and Wagner, 2009). Recently, Di Giuseppe et al. (2012) demonstrated that suspensions containing $<30 \%$ of hard silica spheres had viscoelastic shear-thinning properties while thixotropy appeared at higher concentrations (> 36\%). In Barite Valley dikes, silica and carbonaceous particles represent up to $70 \%$ of the now-solid chert (Fig. 9), but before dewatering and compaction, the concentration would have been lower, perhaps 30 to $40 \%$ (Fig. 14). These particles display a wide range of sizes (from $<1 \mu \mathrm{m}$ to several hundreds of $\mu \mathrm{m}$ ). In heterogeneous suspensions, the larger particles tend to remain dispersed to promote low viscosity under shear stress, while the smaller colloids aggregate more easily and help to develop high viscosity after flowage stops (Usui et al., 2001).

2. Geometry of the grains. Freundlich (1935), a pioneer in rheological studies, observed that platy fine-grained particles cause the viscosity to drop under shear stress, whereas rounded particles tend to restrain thixotropic processes while preserving viscoelastic properties. In our case, the petrography and chemical compositions (Sect. 3.1) reveal the presence of about $5 \%$ of sericite in the dike. Although a minor constituent, the fine, platy mica grains could have promoted the viscosity variations.

3. Polymerization of silica (Lin et al., 1989; Prasher et al., 2006; Chen et al., 2007). In natural siliceous colloidal suspensions like those at hydrothermal vents, viscosity increase is linked to the polymerization of small $(\mathrm{nm})$ to large $(\mu \mathrm{m})$ silica flocs and the formation of coherent 3-D networks or gel-like structures (Iler, 1979; Williams and Crerar, 1985; Bergna, 1994; Channing et al., 2004; Di Giuseppe et al., 2012). During this process, called gelation, hydroxyl groups $(\mathrm{Si}-\mathrm{OH})$ are linked by siloxane bonds ( $\mathrm{Si}-\mathrm{O}-\mathrm{Si}$ ) at the surface of the flocs. The build-up and break-down of the bonds introduces critical stress to the system and plays a major role in viscosity variations: when the critical shear stress is exceeded, the bonds are broken and viscosity drops to a minimum; as the movement decreases, the attraction forces take over and the slurry becomes more viscous. Polymerization is enhanced when other solid particles act as nuclei (Rimstidt and Barnes, 1980; Williams et al., 1985; Williams and Crerar, 1985; Rouchon and Orberger, 2008; Ledevin et al., 2014).

4. Presence of salts in the system (Park et al., 2005; Amiri et al., 2009). The salinity of Archean seawater was prob- 


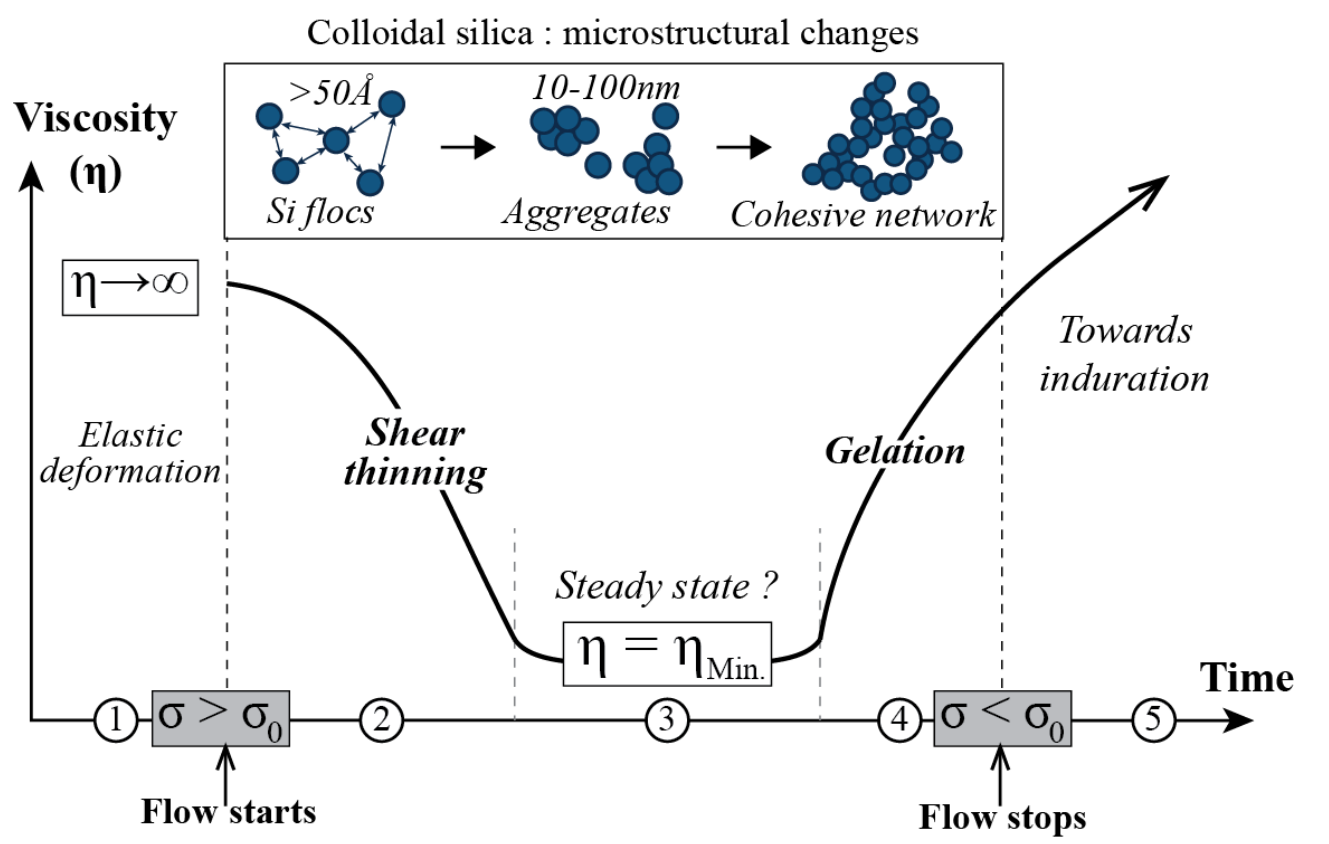

Figure 15. Simplified model showing the expected viscosity variations of the slurry through time. See Sect. 4.3.2 for the description of the various steps. The sketches in the inset illustrate the gelation process of silica that triggered viscosity variations. Floc aggregation starts early within the flow through particle-particle collisions. Then, as the shear stress decreased, the formation of a cohesive silica network rapidly increased the viscosity, and allowed large country rock fragments to stay suspended within the dike.

ably twice that of modern oceans (Knauth, 2005), and the fluids became further enriched in cationic species through water-rock interaction in the crust (i.e. through Si- and K-metasomatism; Hanor and Duchac, 1990; Hofmann and Harris, 2008; Rouchon and Orberger, 2008). Positively charged $\mathrm{Na}^{+}$ions bind to negatively charged $\mathrm{SiO}^{-}$complexes at the surface of silica flocs, thus countering the electrostatic repulsive forces, accelerating gelation and imparting a thixotropic character to the fluid (Marshall and Warakomski, 1980; Chen and Marshall, 1982; Trompette and Meireless, 2003; Park et al., 2005; Amiri et al, 2009).

From the above considerations and comparison with natural examples, we conclude that the characteristics of the slurry in Barite Valley dikes controlled its rheology and promoted strong shear thinning, probably thixotropic, behaviour.

\subsubsection{Simplified rheological model}

Our interpretation of the dynamic behaviour of the slurry is given in Fig. 15. In phase 1, the fluid moved from the elastic to shear-thinning domains as the yield stress $\left(\sigma_{0}\right)$ was exceeded. The slurry was injected quickly (Sect. 4.1) and the transition was rapid. Shearing prevented particle-particle interaction and imparted a very low viscosity to the fluid, which allowed its penetration into even the finest fractures. As the pressure and shear rate decreased (phase 3), the silica flocs aggregated and the viscosity increased rapidly. In phase 4 , the fluid was transformed into a gel strong enough to suspend the large fragments eroded from fracture walls (phase 4). When flowage ceased, the gelified slurry progressively transformed into chert through dehydration, volume loss and microquartz cementation.

Although the complexity of the system makes modelling difficult, we simplify the problem by approximating the yield stress of the slurry. We assume that the country rock fragments remain suspended if the force they exert on the slurry, due to their greater density, is less than the yield stress $\left(\sigma_{0}\right)$. A convenient way to express this equilibrium is to introduce the dimensionless critical yield number $\left(Y_{0}\right)$, which is defined by the ratio between the two forces (Eq. 1) (Beris et al., 1985). This experimental constant varies between 0.1 and 0.6 depending on the nature of the material: it is $0.1-0.4$ for polymeric microgel suspensions (Tabuteau et al., 2007; Putz et al., 2008), but can reach 0.60 for clay suspensions (e.g. Chabra, 2007). We used the values for microgel suspensions (0.1-0.4) in our calculations, in accord with the sub-rounded shape of the particles and polymerization capacity of the matrix:

$$
\begin{aligned}
& Y_{0}=\frac{2 \pi R^{2} \sigma_{0}}{\frac{4}{3} \pi R^{3} \delta \sigma g} \\
& \sigma_{0}=\frac{Y_{0}}{1.5} R \cdot \delta \rho \cdot g
\end{aligned}
$$


Table 3. Composition of the three slurries used for the rheological model of Fig. 16.

\begin{tabular}{|c|c|c|c|}
\hline & \multirow{2}{*}{$\begin{array}{r}\text { Liquid fraction } \\
\text { Si-rich fluid }\end{array}$} & \multicolumn{2}{|c|}{ Particulate fraction } \\
\hline & & Silica & $\begin{array}{r}\text { Carbonaceous } \\
\text { matter }\end{array}$ \\
\hline \multicolumn{4}{|l|}{ Fraction $(\varphi)$} \\
\hline Slurry 1 & 0.6 & 0.3 & 0.1 \\
\hline Slurry 2 & 0.5 & 0.4 & 0.1 \\
\hline Slurry 3 & 0.4 & 0.5 & 0.1 \\
\hline \multicolumn{4}{|l|}{ Density } \\
\hline$\left(\mathrm{g} \mathrm{cm}^{-3}\right)$ & 1.1 & 2.36 & 1.36 \\
\hline
\end{tabular}

From Eq. (1), we obtain the simplified expression (2) which relates the yield stress that prevents sedimentation of the fragments in the slurry to the critical yield number $\left(Y_{0}\right)$, the density difference between the fragments and the slurry $(\delta \rho)$, the characteristic size of the fragments $(R)$ and gravitational acceleration $(g)$. We model $\sigma_{0}$ for three different slurries whose compositions are given in Table 3. We kept the percentage of carbonaceous matter particles at $10 \%$, but varied the proportions of silica particles to investigate low- to highconcentration suspensions. The density of country rock fragments was set at 2.7, which is typical of silicified shales; the density of carbonaceous particles at 1.36 , like modern kerogen values (Huc, 1980), and the density of commercial silica spheres was adopted for the silica particles (e.g. Di Giuseppe et al., 2012). Finally, we arbitrarily set the density of the silica-rich fluid at 1.1, slightly above that of seawater, because of its enrichment in colloidal silica. Results are shown in Fig. 16, where $\sigma_{0}$ is calculated for a range of fragment sizes from $1 \mathrm{~mm}$ to $1 \mathrm{~m}$.

According to this calculation, suspension of the biggest (decimetre sized) fragments in the dikes requires a yield stress around $100 \mathrm{~Pa}$, a value like that of toothpaste or hair gel for example. This model does not take into account the polymerization capacity of silica, which would allow larger fragments to be suspended at a same yield stress (Emady et al., 2013). Accordingly, the critical yield stress was certainly lower than estimated (i.e. $<50-100 \mathrm{~Pa}$ ), although still consistent with the inferred thixotropic properties of the slurry.

\section{Conclusions}

Based on the geometry and internal structure of Barite Valley dikes, and the petrography, chemistry and isotopic composition of the fracture-filling chert, we reach the following conclusions.

- Episodic hydraulic fracturing by overpressured fluids trapped below the sub-seafloor caused intense in situ brecciation of silicified country rocks.

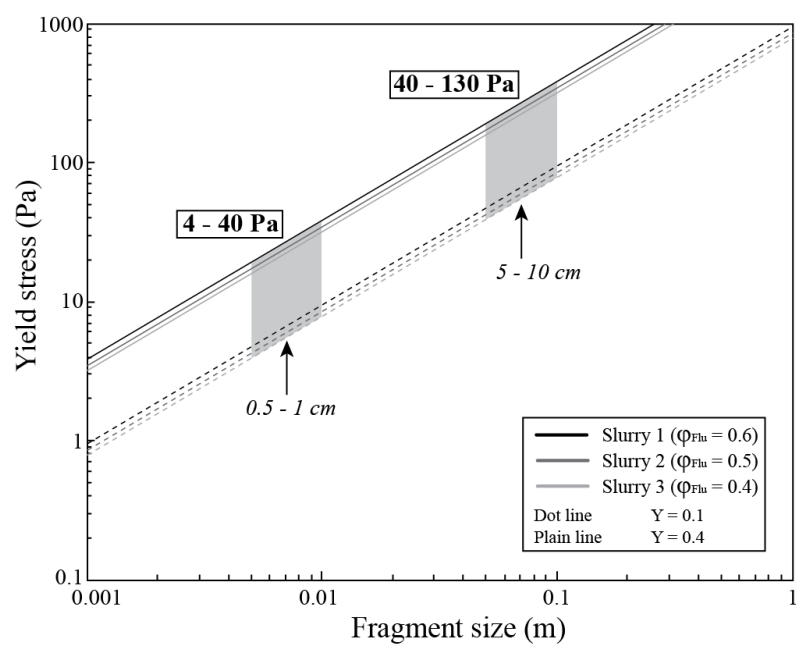

Figure 16. Modelled yield stress of three different slurries depending on the size of the suspended country rock fragments. The yield stress is calculated from Eq. (2) (see text). Slurries 1 to 3 have a fluid fraction of 40,50 and $60 \%$ respectively. A minimum value of 0.1 (dot line) and a maximum of 0.4 (plain line) are taken for the yield number. Results indicate that a yield stress of approximately $100 \mathrm{~Pa}$ is required to prevent the sedimentation of decimetre blocks in the dikes.

- The fracturing medium was a slurry containing solid and colloidal particles in seawater-derived hydrothermal fluids that circulated at low temperature $(<100-$ $150^{\circ} \mathrm{C}$ ) within the shallow crust.

- The slurry exhibited viscoelastic shear thinning, and probably thixotropy. It had very low viscosity when it was injected and become highly viscous after circulation stopped. The presence of clay-sized particles, and the capacity of silica colloids to aggregate and form cohesive 3D networks, accounts for the viscosity variations.

Our approach provides valuable information about the compositions, physical characteristics, and rheological properties of the fluids that circulated through Archean volcanosedimentary sequences. The results indirectly constrain the composition and physical properties of Archean seawater and, when combined with on-going studies of cherts and other sedimentary rocks such as those reported by Stefurak et al. (2014) and Ledevin et al. (2014, 2015), help us understand conditions on the ocean floor, the habitat of early life.

\section{The Supplement related to this article is available online at doi:10.5194/se-6-253-2015-supplement.}


Acknowledgements. We thank the EPOV programme (CNRS) and the ANR project BEGDy (BLAN-0109) for their financial support. We acknowledge François Renard for sharing his expertise in rheological concepts and for improving the paper. For the help in the lab at ISTerre, we thank Etienne Jaillard who contributed to thin section interpretations, Catherine Chauvel, Sarah Bureau and Christelle Poggi for geochemical analyses and Valentina Sobolev for microprobe analyses. For the help in the field, we thank Axel Hofmann and Gordon Chunnett. We especially acknowledge Marc Chaussidon and Claire Rollion-Bard for their involvement in isotopic analyses in Nancy. Finally, we would like to thank Jacqueline Reber as well as anonymous reviewers for their perceptive comments and constructive feedback.

Edited by: F. Rossetti

\section{References}

Amiri, A., Øye, G., and Sjo'blom, J.: Influence of pH, high salinity and particle concentration on stability and rheological properties of aqueous suspensions of fumed silica, Colloids Surf. A, Physicochem. Eng. Aspects, 349, 43-54, 2009.

André, L., Cardinal, D., Alleman, L. Y., and Moorbath, S.: Silicon isotopes in $3.8 \mathrm{Ga}$ West Greenland rocks as clues to the Eoarchaean supracrustal Si cycle, Earth Planet. Sc. Lett., 245, 162173, 2006.

Armstrong, R. A., Compston, W., de Wit, M. J., and Williams, I. S.: The Stratigraphy of the 3.5-3.2 Ga Barberton greenstone belt revisited: a single zircon microprobe study, Earth Planet. Sc. Lett., 101, 90-106, 1990.

Barnes, H. A.: Thixotropy - a review, J. Non-Newton. Fluid, 70, 1-33, 1997.

Bauer, W. H. and Collins, E. A.: Chapter 8, in: Rheology: Theory and Applications, edited by: Eirich, F. R., Academic Press, New York, 1967.

Bergna, H. E.: Colloidal chemistry of silica: An overview, in: The colloidal chemistry of silica, edited by: Bergna, H. E., American Chemical Society, Advances in Chemistry series, 234, 1-47, 1994.

Beris, A., Tsamopoulos, J., Armstrong, R., and Brown, R.: Creeping motion of a sphere through a Bingham plastic, J. Fluid Mech., 158, 219-244, 1985.

Besq, A., Monnet, P., and Pantet, A.: Flow Situations of drilling muds - Effects of thixotropic property, $\mathrm{VI}^{\text {th }}$ international congress Flucome Euro., 8/2000, 2000.

Bolhar, R., Kamber, B. S., Moorbath, S., Fedo, C. M., and Whitehouse, M. J.: Characterization of early Archaean chemical sediments by trace element signatures, Earth Planet. Sc. Lett., 222, 43-60, 2004.

Boswell, P. G. H.: A preliminary examination of the thixotropy of sedimentary rocks, Q. J. Geol. Soc., 104, 499-526, 1948.

Braccini, E., de Boer, W., Hurst, A., Huuse, M., Vigorito, M., and Templeton, G.: Sand injectites, Schlumberger Oilfield Review Summer 2008, 34-49, 2008.

Brasier, M. D., Green, O. R., Jephcoat, A. P., Kleppe, A. K., Van Kranendonk, M. J., Lindsay, J. F., Steele, A., and Grassineau, N. V.: Questioning the evidence of Earth's oldest fossils, Nature, 416, 76-81, 2002.
Brasier, M. D., Green, O. R., and Lindsay, J. F., McLoughlin, N., Steele, A. and Stoakes, C.: Critical testing of Earth's oldest putative fossil assemblage from the $3.5 \mathrm{Ga}$ Apex chert, Chinaman Creek, Western Australia, Prec. Res., 140, 55-102, 2005.

Byerly, G. R., Kröner, A., Lowe, D. R., and Walsh, M. M.: Sequential magmatic evolution of the early Archean Onverwacht Group: evidence from the upper formations, Eos Trans., AGU, 74, 660, 1993.

Byerly, G. R., Kröner, A., Lowe, D. R., Todt, W., and Walsh, M. M.: Prolonged magmatism and time constraints for sediment deposition in the early Archean Barberton greenstone belt: evidence from the Upper Onverwacht and Fig Tree groups, Prec. Res., 78, 125-138, 1996.

Chabra, R. P.: Bubbles, Drops, and Particles in Non-Newtonian Fluids, CRC Press, 2007.

Channer, D. M. D., deRonde, C. E. J., and Spooner, E. T. C.: The Cl-Br-I composition of similar to 3.23 Ga modified seawater: implications for the geological evolution of ocean halide chemistry, Earth Planet. Sc. Lett., 150, 325-335, 1997.

Channing, A., Edwards, D., and Sturtevant, S.: A geothermally influenced wetland containing unconsolidated geochemical sediments, Can. J. Earth Sci., 41, 809-827, 2004.

Chen, C.-T. A. and Marshall, W. L.: Amorphous silica solubilities IV. Behavior in pure water and aqueous sodium chloride, sodium sulfate, magnesium chloride, and magnesium sulfate solutions up to $350^{\circ} \mathrm{C}$, Geochim. Cosmochim. Ac., 46, 279-287, 1982.

Chen, H., Ding, Y., and Tan, C.: Rheological behaviour of nanofluids, New J. Phys., 9, 367, doi:10.1088/1367-2630/9/10/367, 2007.

De La Rocha, C. L., Brzezinski, M. A., and DeNiro, M. J.: Fractionation of silicon isotopes by marine diatoms during biogenic silica formation, Geochim. Cosmochim. Ac., 61, 5051-5056, 1997.

De La Rocha, C. L., Brzezinski, M. A., and DeNiro, M. J.: A first look at the distribution of the stable isotopes of silicon in natural waters, Geochim. Cosmochim. Ac., 64, 2467-2477, 2000.

De Ronde, C. E. J. and de Wit, M. J.: Tectonic history of the Barberton greenstone belt, South Africa: 490 million years of Archean crustal evolution, Tectonics, 13, 983-1005, 1994.

de Vries, S. T., Nijman W., and Armstrong, R.A.: Growthfault structure and stratigraphic architecture of the Buck Ridge volcano-sedimentary complex, upper Hooggenoeg Formation, Barberton Greenstone Belt, South Africa. Prec. Res., 149, 7798, 2006.

de Wit, M. J., Hart, R. J., Martin, A., and Abbott, P.: Archaean abiogenic and probable biogenic structures associated with mineralized hydrothermal vent systems and regional metasomatism, with implications for greenstone belt studies, Econ. Geol., 77, 1783-1802, 1982.

de Wit, M. J., Furnes, H., and Robins, B.: Geology and Tectonostratigraphy of the Onverwacht Suite, Barberton Greenstone Belt, South Africa, Prec. Res., 186, 1-27, 2011.

Di Giuseppe, E., Davaille, A., Mittelstaedt, E., and François, M.: Rheological and mechanical properties of silica colloids: from Newtonian liquid to brittle behavior, Rheol. Acta, 51, 451-465, 2012.

Ding, T., Wan, D., Wang, C., and Zhang, F.: Silicon isotope compositions of dissolved silicon and suspended matter in the Yangtze river, China, Geochim. Cosmochim. Ac., 68, 205-216, 2004. 
Douthitt, C. B.: The geochemistry of the stable isotopes of silicon, Geochim. Cosmochim. Ac., 46, 1449-1458, 1982.

Duchac, K. C. and Hanor, J. S.: Origin and timing of the metasomatic silicification of an early archean komatiite sequence, Barberton mountain land, South Africa, Prec. Res., 37, 125-146, 1987.

Emady, H., Caggioni, M., and Spicer, P.: Colloidal microstructure effects on particle sedimentation in yield stress fluids, J. Rheol., 57, 1761-1772, 2013.

Freundlich, H.: Thixotropy, The Colloidal State, Hermann, in: Actualités scientifiques et industrielles, edited by: Hermann, Paris, 267, 1935.

Furnes, H., De Wit, M.J., Robins, B., and Sandståd, N.R.: Volcanic evolution of the upper Onverwacht Suite, Barberton Greenstone Belt, South Africa, Prec. Res., 186, 28-50, 2011.

Gudmundsson, L.: Rock fractures in geological processes, Cambridge Publication, ISBN 9780521863926, 2011.

Hanor, J. S. and Duchac, K. C.: Isovolumetric silicification of early Archean Komatities: geochemical mass balances and constraints on origin, J. Geol., 98, 863-877, 1990.

Hofmann, A.: The geochemistry of sedimentary rocks from the Fig Tree Group, Barberton greenstone belt: Implications for tectonic, hydrothermal and surface processes during mid- Archaean times, Prec. Res., 143, 23-49, 2005.

Hofmann, A. and Bolhar, R.: Carbonaceous cherts in the Barberton Greenstone Belt and their significance for the study of early life in the Archean record, Astrobiology 7, 355-388, 2007.

Hofmann, A. and Harris, C.: Silica alteration zones in the Barberton greenstone belt: A window into subseafloor processes 3.5-3.3 Ga ago, Chem. Geol., 257, 221-239, 2008.

Huc, A. Y.: Origin and formation of organic matter in recent sediments and its relation to kerogen, in: Kerogen: insoluble organic matter from sedimentary rocks, edited by: Durand, B., Paris, Technip Editions, 445-474, 1980.

Iler, R. K.: The chemistry of silica: Solubility, polymerization, colloid and surface properties, and biochemistry, John Wiley and Sons Inc., New York, 1979.

Jebrak, M.: Hydrothermal breccias in vein-type ore deposits: a review of mechanisms, morphology and size distribution, Ore Geol. Rev., 12, 111-134, 1997.

Jeffrey, D. J. and Acrivos, A.: The rheological properties of suspensions of rigid particles, AIChE J., 22, 417-432, 1976.

Jiang, S. Y., Palmer, M. R., Peng, Q. M., and Yang, J. H.: Chemical and stable isotopic compositions of Proterozoic metamorphosed evaporites and associated tourmalines from Houxianyu borate deposit, eastern Liaoning, China, Chem. Geol., 135, 189211, 1997.

Jobson, D. H., Boulter, G. A., and Foster, R. P.: Structural controls and genesis of epithermal gold-bearing breccias at the Lebong Tandai mine, Western Sumatra, Indonesia, J. Geochem. Explor., 50, 409-428, 1994.

Kiyokawa, S., Ito, T., Ikehara, M., and Kitajima, F.: Middle Archean volcano-hydrothermal sequence: Bacterial microfossil-bearing 3.2 Ga Dixon Island Formation, coastal Pilbara terrane, Australia, Geol. Soc. Am. Bull., 118, 3-22, 2006.

Kiyokawa, S., Ito, T., Ikehara, M., Yamaguchi, K. E., Koge, S., and Sakamoto, R.: Lateral variations in the lithology and organic chemistry of a black shale sequence on the Mesoarchean seafloor affected by hydrothermal processes: The Dixon Island Formation of the coastal Pilbara Terrane, Western Australia, Island Arc., 21, 118-147, 2012.

Knauth, L. P.: Petrogenesis of chert. In: Heaneay, P. J., Prewitt, C. T. and Gibbs, G. V. (Eds.): Silica: Physical behavior, geochemistry and materials applications, Rev. Mineral., 29, 233-256, 1994.

Knauth, L. P.: Temperature and salinity history of the Precambrian ocean: implications for the course of microbial evolution, Palaeogeogr. Palaeoecl., 219, 53-69, 2005.

Knauth, P. L. and Epstein, S.: Hydrogen and oxygen isotope ratios in silica from the JOIDES Deep Sea Drilling Project, Earth Planet. Sc. Lett., 25, 1-10, 1975.

Kröner, A., Byerly, G., and Lowe, D. R.: Chronology of Early Archean granite-greenstone evolution in the Barberton Mountain Land, South Africa, based on precise dating by single zircon evaporation, Earth Planet. Sc. Lett., 103, 41-54, 1991.

Lécuyer, C., Gruau, G., Anhaeusser, C. R., and Fourcade, S.: The origin of fluids and the effects of metamorphism on the primary chemical compositions of Barberton komatiites: new evidence from geochemical (REE) and isotopic $(\mathrm{Nd}, \mathrm{O}, \mathrm{H}$,) data, Geochim. Cosmochim. Ac., 58, 969-984, 1994.

Ledevin, M., Arndt, N., Simionovici, A., Jaillard, E., and Ulrich, M.: Silica precipitation triggered by clastic sedimentation in the Archean: new petrographic evidence from cherts of the Kromberg type section, South Africa, Precam. Res., 255, 316334, 2014.

Ledevin, M., Arndt, N., and Simionovici, A., Physico-chemical variations in Archean seawater and the precipitation of blackand-white banded cherts from the Buck Reef, Barberton Greenstone Belt, South Africa, in preparation, 2015.

Li, J.-W., Zhou, M.-F., Li, X.-F., Li, Z.-J., and Fu, Z.-R.: Origin of a large breccia-vein system in the Sanerlin uranium deposit, southern China: a reinterpretation, Min. Deposita, 37, 213-225, 2002.

Li, Y., Ding, T., and Wan, D.: Experimental stdy of silicon isotope dynamic fractionation and its application in geology, Chinese J. Geochem., 14, 212-219, 1995.

Lin, M. Y., Lindsay, H. M., Weitz, D. A., Ball, R. C., Klein, R., and Meakin, P.: Universality of colloid aggregation, Nature, 339, 360-362, 1989.

Lowe, D. R.: Crustal fracturing and chert dike formation triggered by large meteorite impacts, ca. $3.260 \mathrm{Ga}$, Barberton greenstone belt, South Africa, Geol. Soc. Am. Bull., 125, 894-912, 2013.

Lowe, D. R. and Byerly, G. R.: Archaean flow-top alteration zones formed initially in a low temperature sulphate-rich environment, Nature, 324, 245-248, 1986a.

Lowe, D. R. and Byerly, G. R.: Early Archean silicate spherules of probable impact origin, South Africa and Western Australia, Geology 14, 83-86, 1986b.

Lowe, D. R. and Byerly, G. R.: Field Guide to the Geology of the 3.5-3.2 Ga Barberton Greenstone Belt, South Africa, Guidebook prepared for Field Conference: Archean Surface Processes, 184, 2003.

Lowe, D. R. and Knauth L. P.: Sedimentology of the Onverwacht Group (3.4 billion years), Transvaal, South Africa, and its bearing on the characteristics and evolution of the early earth, J. Geol., 85, 699-723, 1977.

Lowe, D. R. and Nocita, B. W.: Foreland basin sedimentation in the Mapepe Formation, southern-facies Fig Tree Group, Geological Society of America Special Paper, 329, 233-258, 1999. 
Maccaferri, F., Bonafede, M., and Rivalta, E.: A quantitative study of the mechanisms governing dike propagation, dike arrest and sill formation, J. Volc. Geoth. Res., 208, 39-50, 2011.

Marin, J., Chaussidon, M., and Robert, F.: Microscale oxygen isotope variations in $1.9 \mathrm{Ga}$ Gunflint cherts: Assessments of diagenesis effects and implications for oceanic paleotemperature reconstructions, Geochim. Cosmochim. Ac., 74, 116-130, 2010.

Marin-Carbonne, J., Chaussidon, M., and Robert, F.: Micrometerscale chemical and isotopic criteria $(\mathrm{O}$ and $\mathrm{Si})$ on the origin and history of Precambrian cherts: Implications for paleotemperature reconstructions, Geochim. Cosmochim. Ac., 92, 129-147, 2012.

Marone, C. and Scholtz, C. H.: Particle-size distribution and microstructures within simulated fault gouge, J. Struct. Geol., 11, 799-814, 1989.

Marshall, W. L. and Warakomski, J. M.: Amorphous silica solubilities - II. Effect of aqueous salt solutions at $25^{\circ} \mathrm{C}$, Geochim. Cosmochim. Ac., 44, 915-924, 1980.

Mewis, J. and Wagner, N. J.: Thixotropy, Adv. Colloid Interfac., 147-148, 214-227, 2009.

Nguyen, Q. D. and Boger, D. V:. Thixotropic behaviour of concentrated bauxite residue suspensions, Rheol. Acta, 24, 427-437, 1985.

Nijman, W., de Bruijne, K. C., and Valkering, M. E.: Growth fault control of Early Archaean cherts, barite mounds and chert-barite veins, North Pole Dome, Eastern Pilbara, Western Australia, Precam. Res., 88, 25-52, 1998.

Oleksy, M., Heneczkowski, M., and Galina, H.: Thixotropic compositions: unsaturated polyester resins/ modified bentonites, Polimery, 5, 345-350, 2007.

Paris, I., Stanistreet, I. G., and Hughes, M. J.: Cherts of the Barberton Greenstone Belt Interpreted as Products of Submarine Exhalative Activity, J. Geol., 93, 111-129, 1985.

Park, J., Park, S. B., Yang, S. M., Hong, W. H., Choi, C. R., and Kim, J. H.: Rheological characterization and optimization of gelled electrolyte for sealed lead-acid batteries by small amplitude dynamic oscillation measurement, J. Non-Cryst. Solids, 351, 2352-2357, 2005.

Perry, E. C. and Lefticariu, L.: Formation and Geochemistry of Precambrian cherts, Treatise of geochemistry, 7, 99-113, 2003.

Prasher, R., Evans, W., Meakin, P., Fish, J., Phelan, P., and Keblinski, P.: Effect of aggregation on thermal conduction in colloidal nanofluids, Appl. Phys. Lett., 89, 143119, doi:10.1063/1.2360229, 2006.

Putz, M. V., Burghelea, T. I., Frigaard, I. A., and Martinez, D. M.: Settling of an isolated spherical particle in a yield stress shear thinning fluid, Phys. Fluids, 20, 033102-033102-11, 2008.

Rimstidt, J. D. and Barnes, H. L.: The kinetics of silica-water interaction, Geochim. Cosmochim. Ac., 44, 1683-1699, 1980.

Rouchon, V. and Orberger, B.: Origin and mechanisms of K-Simetasomatism of ca. 3.4-3.3 Ga volcaniclastic deposits and implications for Archean seawater evolution: Examples from cherts of Kittys Gap (Pilbara craton, Australia) and Msauli (Barberton Greenstone Belt, South Africa), Precam. Res., 165, 169-189, 2008.
Sleep, N. H. and Lowe, D. R.: Physics of crustal fracturing and chert dike formation triggered by asteroid impact, $\sim 3.26 \mathrm{Ga}$, Barberton greenstone belt, South Africa, Geochem. Geophys. Geosyst., 15, 1054-1070, 2014.

Stefurak, E. J., T., Lowe, D. R., Zentner, D., and Fischer, W. W.: Primary silica granules - A new mode of Paleoarchean sedimentation, Geology, 42, 283-286, 2014.

Stickel, J. J. and Powell, R. L.: Fluid mechanics and rheology of dense suspensions, Annu. Rev. Fluid. Mech., 37, 129-149, 2005.

Tabuteau, H., Coussot, P., and de Bruyn, J. R.: Drag force on a sphere in steady motion through a yield-stress fluid, J. Rheol. 51, 125-137, 2007.

Taylor, S. R. and McLennan, S. M.: The Continental Crust: its composition and evolution, Blackwell Scientific Publications, pp. 312, 1985.

Thompson, B. J., Moore, J. C., and Garrison, R. E.: A reservoirscale Miocene Injectite near Santa Cruz, California, in: Sand Injectites: Implications for hydrocarbon exploration and production, edited by: Hurst, A. and Cartwright, J., AAPG Memoir, 87, 151-162, 2007.

Trompette, J. L. and Meireles, M.: Ion-specific effect on the gelation kinetics of concentrated colloidal silica suspensions, J. Colloid Interface Sci., 263, 522-527, 2003.

Ueno, Y., Yoshioka, H., Maruyama, S., and Isozaki, Y.: Carbon isotopes and petrography of kerogens in $\sim 3.5$-Ga hydrothermal silica dikes in the North Pole area, Western Australia, Geochim. Cosmochim. Ac., 68, 573-589, 2004.

Usui, H., Kishimoto, K., and Suzuki, H.: Non-Newtonian viscosity of dense slurries prepared by spherical particles, Chem. Eng. Sc., 56, 2979-2989, 2001.

Van den Boorn, H. J. M., van Bergen, M. J. J., Vroon, P. Z. Z., de Vries, S. T. T., and Nijman, W.: Silicon isotope and trace element constraints on the origin of $3.5 \mathrm{Ga}$ cherts: Implications for Early Archaean marine environments, Geochim. Cosmochim. Ac., 74, 1077-1103, 2010.

Van Kranendonk, M. J.: Volcanic degassing, hydrothermal circulation and the flourishing of early life on Earth: a review of the evidence from ca. 3490-3240 Ma rocks of the Pilbara Supergroup, Pilbara Craton,Western Australia, Earth-Sci. Rev., 74, 197-240, 2006.

Williams, L. A. and Crerar, D. A.: Silica diagenesis ; II, General mechanisms. J. Sedim. Res., 55, 312-321, 1985.

Williams, L. A., Parks, G. A., and Crerar, D. A.: Silica diagenesis, I. Solubility controls. J. Sedim. Petro., 55, 301-311, 1985.

Yanez, J. A., Laarz, E., and Bergstrm, L.: Viscoelastic properties of particle gels, J. Colloid Interface Sci., 209, 162-172, 1999 